\title{
Albania: Fiscal Transparency Evaluation
}




\title{
INTERNATIONAL MONETARY FUND
}

IMF Country Report No. 16/5

\section{ALBANIA}

\section{FISCAL TRANSPARENCY EVALUATION}

January 2016

This Fiscal Transparency Evaluation for Albania was prepared by a staff team of the International Monetary Fund based on the information available at the completion of their visit to Tirana on June 16, 2015.

\author{
Copies of this report are available to the public from \\ International Monetary Fund • Publication Services \\ PO Box 92780 • Washington, D.C. 20090 \\ Telephone: (202) 623-7430 • Fax: (202) 623-7201 \\ E-mail: publications@imf.org Web: http://www.imf.org \\ Price: $\$ 18.00$ per printed copy
}

\section{International Monetary Fund \\ Washington, D.C.}

(C) 2016 International Monetary Fund

CInternational Monetary Fund. Not for Redistribution 


\section{INTERNATIONAL MONETARY FUND}

\section{Fiscal Affairs Department}

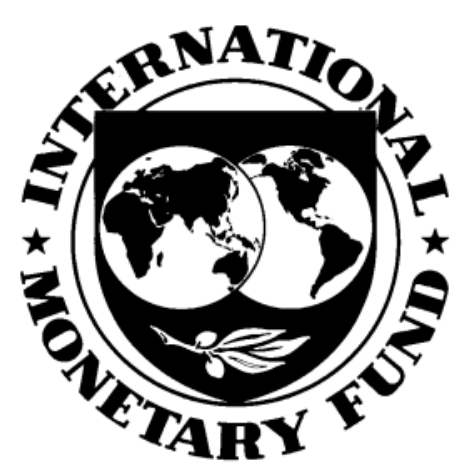

\section{ALBANIA}

\section{FISCAL TRANSPARENCY EVALUATION}

Tim Irwin, Suzanne Flynn, Tom Josephs, Linda Spahia, and Rod O'Mahony

November 2015 


\section{CONTENTS}

Preface

I. FISCAL REPORTING

A. Coverage of Fiscal Reports $\underline{12}$

B. Frequency and Timeliness of Fiscal Reporting $\underline{17}$

C. Quality of Fiscal Reports $\underline{18}$

D. Integrity of Fiscal Reports $\underline{19}$

E. Conclusions and Recommendations $\underline{20}$

II. FISCAL FORECASTING AND BUDGETING___ $\underline{22}$

A. Comprehensiveness___ $\underline{23}$

B. Orderliness__ $\underline{29}$

C. Policy Orientation___ $\underline{30}$

D. Credibility__ $\underline{31}$

E. Conclusions and Recommendations ___ $\underline{36}$

III. FISCAL RISKS_________ 38

A. Disclosure and Analysis ___ $\underline{39}$

B. Risk Management__ 42

C. Coordination__ 47

D. Conclusions and Recommendations___ $\underline{50}$

BOX

2.1. Example of Forecast Reconciliation

\section{FIGURES}

1.1. Public Sector Balance Sheet and Coverage in Fiscal Reports___ 14

1.2. Liabilities of the Public Sector, Selected Countries ___ 14

2.1. Social Security Contributions and Own-Source Revenues, Selected Countries __ 24

2.2. Forecasts and Outturn for Real GDP Growth ___ 25

2.3. Average Forecast Errors for Real GDP Growth, Albania and EU Countries___ $\underline{25}$

2.4. Revenue Forecast Errors__ $\underline{26}$

2.5. Difference Between Expenditure Projections and Outturns ___ 27

2.6. Gross Capital Expenditure of General Government, EU and Selected Countries___ $\underline{28}$

2 INTERNATIONAL MONETARY FUND

CInternational Monetary Fund. Not for Redistribution 
2.7. Difference Between Expenditure Plans and Outturn $\underline{28}$

2.8. Changes to the Submitted Budget __ 32

2.9. Difference Between Submitted Budget and Outturn in Selected Countries __

2.10. Difference Between Successive Forecasts and Final Outturns ___ 33

2.11. Comparison of Macro and Fiscal Forecast Errors (Percentage Points)___ 34

2.12. Decomposition of Errors in the Forecast of Gross Debt (Percent GDP) __ $\underline{35}$

3.1. Volatility of Real GDP and Government Revenue, European Countries___ 40

3.2. Projection of Pension Scheme's Balance, 2014-78___ 42

3.3. General Government Guarantees by Sector, March 2015

3.4. General Government Guarantees, Europe, 2014 _ 44

3.5. Nonperforming Loans in Selected European Countries, 2014 _ 46

3.6. Spending of Local Government in European Countries, 2014___ 48

3.7. Unconsolidated Liabilities of Largest Public Corporations, $2013 \_49$

3.8. Liabilities of Public Corporations, European Countries, 2013 _ 49

\section{TABLES}

0.1 Summary Assessment Against the Fiscal Transparency Code ___ $\underline{9}$

1.1. Published Fiscal Reports __ 11

1.2. Composition of the Public Sector___ 12

1.3. Summary Accounts of the Public Sector, 2013

1.4. Balance Sheet of General Government, 2013

1.5. Cash-Flow Reconciliation for General Government, $2013 \ldots 16$

1.6. Value of Tax Expenditures __

1.7. Reconciliation of the Deficit With Changes in Debt, 2013__

1.8. Summary Evaluation of Albania's Fiscal Reporting ___ 21

2.1. Fiscal Forecasting and Budget Documents __ $\underline{23}$

2.2. Dates of Budget Submission and Approval __ 30

2.3. Composition of Forecast Errors (Million Lek) ___ 34

2.4. Decomposition of Errors in the Forecast of Interest Payments (Million Lek)__

2.5. Summary Evaluation of Fiscal Forecasting and Budgeting ___ 37

3.1. Albania: Selected Reports Discussing Fiscal Risks ___ 39

3.2. Size of Selected Specific Fiscal Risks Not Quantified in Budget, Recent Estimates ___ 41

3.3. Bank Liabilities, 2013 _ 46

3.4. Summary Evaluation: Fiscal Risks __ 51 


\section{Preface}

In response to a request by the Government of Albania, a mission from the Fiscal Affairs Department of the IMF visited Tirana from June 4 to 16, 2015, to carry out a Fiscal Transparency Evaluation. The mission included Tim Irwin, Suzanne Flynn, and Tom Josephs of the Fiscal Affairs Department, as well as Linda Spahia of the IMF's Resident Representative Office in Tirana and Rod O'Mahony, an expert in government finance statistics. ${ }^{1}$

At the Ministry of Finance, the mission met Mr. Erjon Luçi, the Deputy Minister of Finance; Ms. Gelardina Prodani, the General Secretary; Ms. Mimoza Dhëmbi, the General Director of the Budget; Ms. Arjana Dyrmishi, the General Director of Fiscal Policy and Public Revenues; Mr. Endrit Lami, the General Director of Macroeconomics; and Ms. Adela Xhemali, the General Director of Financial Services. It also met, among other people, Ms. Mimoza Peço and Ms. Anxhela Kasapi of the treasury; Mr. Genti Opre and Mr. Fran Brahimi of the budget department; and Mr. Dritan Fino, an advisor to the Minister of Finance.

Outside the Ministry of Finance, the mission met Ms. Ilda Malile of the Ministry of the Economy, Mr. Gjergji Mano and Mr. Enton Alika of the Institute of Statistics, Ms. Luljeta Nano and Ms. Manjola Naço of the Supreme State Audit, Mr. Ali Emini and Mr. Astrit Hado of the Institute of Social Insurance, Mr. Klodian Shehu of the Bank of Albania, several members of the Parliamentary budget committee, Ms. Edina Halapi-Stansfield of the European Commission, Ms. Sigita Stafa of the delegation of the Swiss government, and Ms. Aranita Brahaj of the Albanian Institute of Science.

The mission would like to thank all these people for their help. It would also like to thank Ms. Esi Fezolli for arranging its meetings.

\footnotetext{
${ }^{1}$ Advice and other assistance was provided by Miguel Alves, Ezequiel Cabezon, Kerstin Gerling, Sybi Hida, Nadeem Ilahi, Duncan Last, Brian Olden, Kara Rideout, and Slavi Slavov.
} 


\section{EXECUTIVE SUMMARY}

This assessment of the information the Government of Albania publishes on its finances finds that many of the fundamental elements of fiscal transparency are now in place:

- $\quad$ The budget clearly shows the government's forecasts of revenue and its plans for spending and for financing the deficit. It is also detailed, showing spending on each of several hundred government programs.

- Reports on the implementation of the budget are frequent, timely, and comprehensive (though they do not consolidate public corporations). Basic data on revenue and spending are published monthly, usually no more than 20 days after the end of the month. Quarterly and annual reports give more detailed information. There are even daily reports listing each government payment.

- The government's direct and guaranteed debt is reported every three months. Every loan, treasury bill, bond, and guarantee is individually disclosed, and the composition of the government's debt is analyzed in ways that allow investors and others to understand the associated risks.

- The government also discloses many other sources of fiscal risk. It describes the consequences for the deficit of lower-than-forecast economic growth, and it discusses the risks created by banks, some public investment projects, and the cost of compensating previous owners for land expropriated during the communist era. The budget also limits the value of guarantees that can be issued during the year, and local governments' borrowing is strictly controlled by the Ministry of Finance.

As a result, Albania meets at least the standard of basic practice on 24 of the 36 dimensions of the IMF's Fiscal Transparency Code. On 10 dimensions, it meets the standard of good or advanced practice. (See Tables 1.8, 2.4, and 3.4.) This achievement is all the more impressive given the country's relatively brief history of democracy. ${ }^{2}$

Yet there are problems with the quality and reliability of some fiscal information, or at least with the mechanisms for assuring its quality:

- $\quad$ Over the past decade, the government's budgets have on average overestimated revenue by about 2 percent of GDP, which has encouraged unrealistic spending plans that the government has had to cut back during the year. No independent fiscal council evaluates

\footnotetext{
${ }^{2}$ For earlier assessments of fiscal transparency in Albania, see IMF, Albania: Report on Observance of Standards and Codes-Fiscal Transparency, 2003, and International Budget Partnership, Open Budget Survey, 2012. The 2003 IMF report on fiscal transparency is not directly comparable to this one because it assessed Albania's practices against an earlier version of the fiscal-transparency code. But it is clear there have been improvements since 2003. For example, the 2003 report finds that only aggregate information on debt is available, while this report notes that detailed breakdowns of debt are published. The 2003 report notes that fiscal data are published quarterly, while this one notes that they are published monthly. It is also clear that much more information on fiscal risks is published. The Open Budget Surveys for different years are directly comparable and according to the 2012 survey Albania had one of the largest increases in transparency in the world between 2006 and 2012.
} 
the government's forecasts, and the government does not explain why each new forecast differs from the prior one. Nor does the government compare its forecasts with those of other institutions or with actual outcomes. The problem of unrealistic forecasts undermines what would otherwise be a transparent and effective system of budgeting and medium-term fiscal planning.

- $\quad$ The Supreme State Audit does not offer an opinion on whether the government's financial reports fairly represent public finances, and the Institute of Statistics has neither the resources nor the safeguards of independence to produce fully credible fiscal statistics. (At present, there is little or no difference in Albania between the financial reports produced by accountants and the fiscal statistics produced by statisticians, but the international rules for producing accounts and statistics differ in some respects.)

- The government's fiscal reports contain few reconciliations of stocks and flows. For example, no report explains how the change in the government's debt can be reconciled with the budget deficit. This increases the risks of errors and of hidden off-budget spending and, more generally, makes it hard for the public to see how everything adds up.

- Finally, information is not always clearly presented and explained. Several departments of the Ministry of Finance publish similar reports on aspects of public finances, which leads to duplication that in practice reduces transparency. While outturns are presented alongside budget plans, there is little explanation of the main reasons for major differences. There is also no "citizens' budget" that summarizes the main features of the budget in a simple manner.

Nor are the fundamental elements of transparency always sufficient to fully describe public finances. In particular, the reporting of traditionally measured spending and debt can miss important developments in public finances that show up only in other more sophisticated kinds of data. For example, cash-based measures of spending can miss costs that are revealed by "accrual" measures that record the economic effect of events even when no cash changes hands. These accrual measures link the government's revenue and spending to a balance sheet that includes not just debt, but assets and other liabilities. Although the government's accounting includes elements of accrual measurement, the absence of a fully developed system, and of other disclosures, causes various problems:

- $\quad$ The government pays senior civil servants and members of the police and military partly by promising them pensions when they retire. Yet the economic cost of these promises does not show up now in the government's reported deficit. The budget does include payments to current retirees, but because the pension scheme for government employees is young, these payments may be much less than the increase in the government's liability to future retirees. The government's pension liability is undisclosed and is estimated to be in the region of 1.4 percent of GDP.

- $\quad$ Although current and capital expenditure are distinguished in the budget, the absence of a reliable balance sheet makes it hard to tell whether the government's spending is building and maintaining the country's essential infrastructure. 
- The government is also financing some public investments by means of public-private partnerships, in which it will either pay the cost of the investment in installments or guarantee the revenue of concessionaires that will collect tolls from road users. Modern accounting standards would require the government to record the investment in at least some of these projects as debt-financed government spending. The government's traditional accounting does not do this. There are also gaps in the information provided on the costs of publicly financed investments that take longer to carry out than the three-year horizon of the government's budgeting. One outcome has been the build-up of significant payment arrears in recent years.

The government promotes investment and other activities by giving tax exemptions to certain kinds of businesses and by taxing some goods and services at lower rates than others. These so-called tax expenditures are like ordinary expenditures in that they must be paid for by levying higher taxes on other businesses or activities. Yet the government does not report on them.

The government has plans to tackle some of these problems. ${ }^{3}$ For example, it intends to develop accrual accounting, and a recently enacted audit law allows the Supreme State Audit to give an opinion on the government's accounts. The Ministry of Finance and the Institute of Statistics are also working to improve fiscal statistics, so that they include more of the information required by the IMF and the European Union. Getting fully satisfactory fiscal information is difficult even in advanced economies, ${ }^{4}$ and the government should not be expected to solve all the problems immediately. Making progress is important, however, if the government is to maintain control over public finances, demonstrate its accountability to the public, and satisfy the requirements of the European Union. One of the difficulties the government faces is to develop more sophisticated information without creating unnecessary complexity and without losing the tight connection that currently exists between the budget and retrospective fiscal reports.

The rest of this report assesses Albania's practices against the standards set out in the IMF's Fiscal Transparency Code and makes recommendations designed to address the most pressing of the problems. It has three parts. The first looks at fiscal reporting, including the monthly, quarterly, and annual publications on the implementation of the budget. The second considers the budget and fiscal forecasts. The third examines the disclosure and management of fiscal risks. In each section, the report assesses not only whether Albania meets the standards of basic, good, and advanced practice set out in the Code, but also how important any shortcomings are, given Albania's particular circumstances. On the basis of this analysis, it recommends that the government:

- Include a partial balance sheet in fiscal reports, along with tables that reconcile changes in the debt with the deficit and changes in cash balances with cash flows;

\footnotetext{
${ }^{3}$ See, in particular, Ministry of Finance, Albania: Public Finance Management Strategy, 2014-20, December 2014.

${ }^{4}$ Fiscal Transparency Evaluations for Finland, Ireland, and Portugal, among other countries, are available at http://www.imf.org/external/np/fad/trans/.
} 
- Simplify fiscal reports by producing a single set of monthly, quarterly, and annual reports that incorporate the information currently reported separately by the treasury, the debt department, the budget department, and the macroeconomic department;

- Publish an annual report on tax expenditures that estimates the revenue foregone by all major tax exemptions and other tax privileges;

- $\quad$ Enhance the scrutiny of its macroeconomic and fiscal forecasts by publicly comparing them with those of other institutions, by reconciling new forecast with prior forecasts and actual outcomes, and by considering whether to establish an independent fiscal council;

- Improve the transparency of public investment projects, including public-private partnerships, by, among other things, routinely publishing cost-benefit analyses and disclosing the total value of the government's commitments, project by project; and

- $\quad$ Progressively increase the scope and depth of the report on fiscal risks in the budget document, so that it also describes the fiscal implications of public-private partnerships, the finances of public corporations, and the long-term risks created by pensions, healthcare, and other spending programs.

- $\quad$ Put in place appropriate measures to ensure comprehensive oversight of all public corporations.

The key findings of the evaluation are presented in Table 0.1 below and ranked according to their relative importance for fiscal management. 
Table 0.1 Albania: Summary Assessment Against the Fiscal Transparency Code

\begin{tabular}{|c|c|c|c|}
\hline \multirow{2}{*}{$\begin{array}{l}\text { LEVEL OF } \\
\text { IMPORTANCE }\end{array}$} & \multicolumn{3}{|c|}{ LEVEL OF PRACTICE } \\
\hline & I. FISCAL REPORTING & $\begin{array}{l}\text { II. FISCAL FORECASTING } \\
\text { AND BUDGETING }\end{array}$ & $\begin{array}{l}\text { III. FISCAL RISK ANALYSIS \& } \\
\text { MANAGEMENT }\end{array}$ \\
\hline \multirow{6}{*}{ HIGH } & 1.1.2 Coverage of Stocks & $\begin{array}{c}\text { 2.1.2 Macroeconomic } \\
\text { Forecasts }\end{array}$ & 3.1.2 Specific Fiscal Risks \\
\hline & $\begin{array}{l}\text { 1.2.2 Timeliness of Annual } \\
\text { Financial Statements }\end{array}$ & 2.1.3 Medium-Term Budget & $\begin{array}{l}\text { 3.2.2 Asset and Liability } \\
\text { Management }\end{array}$ \\
\hline & 1.3.2 Internal Consistency & 2.1.4 Investment Projects & $\begin{array}{l}\text { 3.2.5 Financial Sector } \\
\text { Exposure }\end{array}$ \\
\hline & 1.4.2 External Audit & 2.4.1 Independent Evaluation & 3.3.2 Public Corporations \\
\hline & & 2.4.2 Supplementary Budget & $\begin{array}{l}\text { 3.3.1 Sub-National } \\
\text { Governments }\end{array}$ \\
\hline & & 2.4.3 Forecast Reconciliation & \\
\hline \multirow{5}{*}{ MEDIUM } & $\begin{array}{l}\text { 1.1.1 Coverage of } \\
\text { Institutions }\end{array}$ & 2.3.1 Fiscal Policy Objectives & 3.1.1 Macroeconomic Risks \\
\hline & 1.1.3 Coverage of Flows & $\begin{array}{l}\text { 2.3.2 Performance } \\
\text { Information }\end{array}$ & $\begin{array}{l}\text { 3.1.3 Long-Term Fiscal } \\
\text { Sustainability Analysis }\end{array}$ \\
\hline & 1.1.4 Tax Expenditures & 2.3.3 Public Participation & 3.2.1 Budgetary Contingencies \\
\hline & 1.4.1 Statistical Integrity & & 3.2.3 Guarantees \\
\hline & $\begin{array}{c}\text { 1.4.3 Comparability of Fiscal } \\
\text { Data }\end{array}$ & & $\begin{array}{l}\text { 3.2.4 Public Private } \\
\text { Partnerships }\end{array}$ \\
\hline \multirow{3}{*}{ LOW } & $\begin{array}{l}\text { 1.2.1 Frequency of In-Year } \\
\text { Reporting }\end{array}$ & 2.1.1 Budget Unity & 3.2.6 Natural Resources \\
\hline & 1.3.1 Classification & 2.2.1 Fiscal Legislation & 3.2.7 Environmental Risks \\
\hline & 1.3.3 Historical Consistency & $\begin{array}{c}\text { 2.2.2 Timeliness of Budget } \\
\text { Documents }\end{array}$ & \\
\hline
\end{tabular}

\section{Legend for Tables}

\section{Practice under Fiscal Transparency Code}

\begin{tabular}{l|lll} 
& Not Met & Basic Good Advanced
\end{tabular}

\section{Importance to Fiscal Management}

\begin{tabular}{c|c|c|c|}
\hline & \multicolumn{3}{c}{ LEVEL OF PRACTICE } \\
LEVEL OF & High & Medium & Low \\
IMPORTANCE & & & \\
\hline
\end{tabular}




\section{FISCAL REPORTING}

1. This section assesses the quality of fiscal reports against the principles of the Code. It assesses in particular whether fiscal statistics, financial statements, and in-year and end-of-year budget-execution reports:

- $\quad$ Cover all institutional units engaged in fiscal activity for the whole public sector;

- Record all assets and liabilities and all revenue, expenditure, financing, and other economic flows;

- $\quad$ Are published in a frequent and timely manner;

- $\quad$ Are classified according to international standards;

- $\quad$ Are comparable with each other and reconcile different balances; and

- $\quad$ Are prepared by an independent agency (in the case of statistics) or are scrutinized by an independent auditor (in the case of accounts).

2. Fiscal reports in Albania have many good features. They show revenue and expenditure, financing, and the debt of the general government, including guaranteed debt (Table 1.1). They consolidate general government in line with international standards and are prepared monthly, quarterly, and annually in a timely manner. They also reconcile the government's deficit with its borrowing and other sources of financing.

3. Data on the government's balance sheet are fragmented and incomplete. Detailed debt data are published on the Ministry of Finance's website. The government's cash balance, however, is published only on the Bank of Albania's website, while information on accounts payable is provisional, unaudited, and unpublished. Debt and cash balances are not reconciled with fiscal flows.

4. Some reports duplicate information, while others could be improved. For example, the monthly and quarterly reports produced by the treasury department show public debt, which is also the subject of the reports produced by the debt department. The reports produced by the treasury also overlap with those published by the macroeconomic department. While each report offers new information, it would be better if the Ministry of Finance produced a single report that provided all the relevant information. Quarterly and annual reports should also show opening and closing cash and debt, reconciled to the flows during the period. The annual report on implementation of the budget lacks summary data on final budget outturns by economic, functional, and program classification. It also lacks a full set of financial statements, notably a cash-flow statement and a balance sheet. 


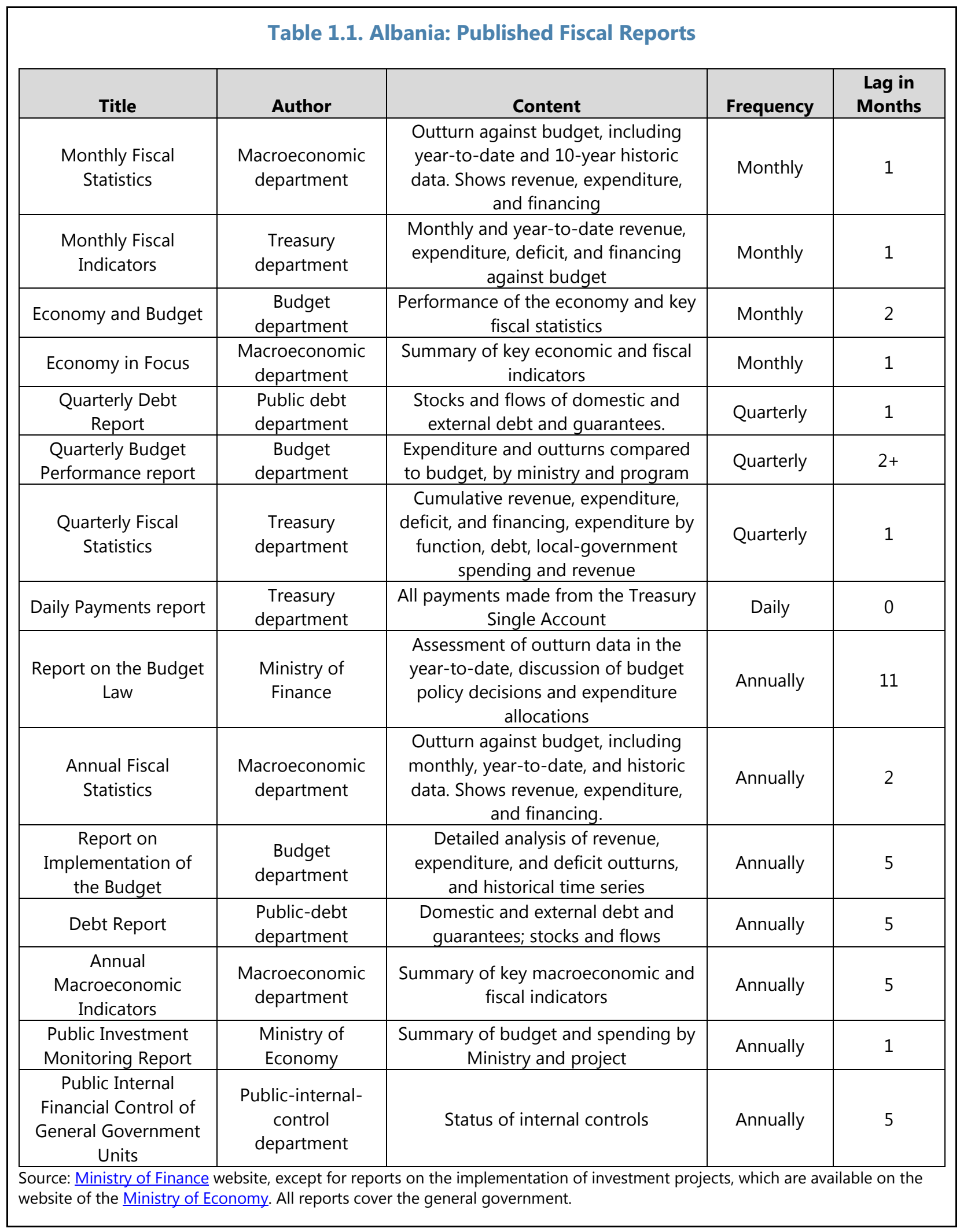




\section{A. Coverage of Fiscal Reports}

\subsubsection{Coverage of institutions (Basic)}

5. The public sector includes about 1,500 separate entities (Table 1.2). The precise number is unknown, but efforts are underway to compile a full list. Most of the known entities are part of the central government. There also about 385 entities in the local-government sector, though the number is expected to fall to 61 after the implementation of a new law, after the July 2015 elections. There are also two funds in the social-security sector, one for pensions and one for health insurance. The public sector also includes the central bank and 255 unlisted public corporations that are owned or controlled by entities in general government- 58 owned by the local government sector, the remaining by central government. Almost all the public corporations are nonfinancial; the largest of the financial corporations, other than the Bank of Albania, is an insurance company, Insig (see Section 3.3.2).

\begin{tabular}{|cr|}
\hline Table 1.2. Albania: Composition of the Public Sector \\
\hline & $\begin{array}{r}\text { Number of } \\
\text { Entities }\end{array}$ \\
\hline Public Sector (I + II) & 1,469 \\
I. General Government (A + B + C) & 1,213 \\
A. Central Government & 826 \\
Budgetary central government & 799 \\
Extrabudgetary units & 27 \\
B. Local Government & 385 \\
C. Social Security & 2 \\
Health Insurance Fund & 1 \\
Social Security Fund & 1 \\
II. Public Corporations & 256 \\
Source: Ministry of Finance and Institute for Statistics. \\
\hline
\end{tabular}

\section{Fiscal reports consolidate most entities in general government, but not public} corporations. The coverage of general government is good, but not complete: there appear to be about 27 entities (extrabudgetary units in Table 1.2) that are part of central government according to statistical rules that are not consolidated in the reports of general government. They include the civil-aviation authority, the deposit insurance corporation, and moribund companies that are in the process of being closed down. There is no published financial information for these entities. The inclusion of these entities in fiscal reports would be relatively easy, and lead to an increase in the rating. Figure 1.1 shows the coverage of the various sectors in the fiscal reports.

7. Table 1.3 presents an estimate of public sector accounts for 2013, the most recent year for which data are available. It incorporates the accounts of the Bank of Albania and the 12 largest other public corporations by revenue. The estimates for the public sector in the right-hand column are not the sum of the components in the other columns: some large transactions and claims that 
are internal to the public sector, such as the Bank of Albania's liabilities to the general government, have been eliminated in the consolidation.

\begin{tabular}{ll}
\multicolumn{5}{|c|}{ Table 1.3. Summary Accounts of the Public Sector, 2013} \\
(Percent of GDP)
\end{tabular}

\section{The accounts show that expanding the institutional coverage of fiscal reports to} include public corporations would have increased the debt and deficit. The liabilities of the public sector were about 119 percent of GDP, whereas those of the general government (debt and accounts payable) were about 83 percent of GDP. At the same time, public corporations have valuable assets, and the rough estimate in the table implies that the public sector had a small positive net worth. In 2013, the Bank of Albania and other public corporations (including the electricity companies) made a loss, and the estimated deficit of the public sector was 6.8 percent of GDP, compared to 5.2 percent for the general government. Although the liabilities of public corporations are substantial, they are not especially high by international standards (Figure 1.2). 
Figure 1.1 Albania: Public Sector Balance Sheet and Coverage in Fiscal Reports (Percent of GDP)

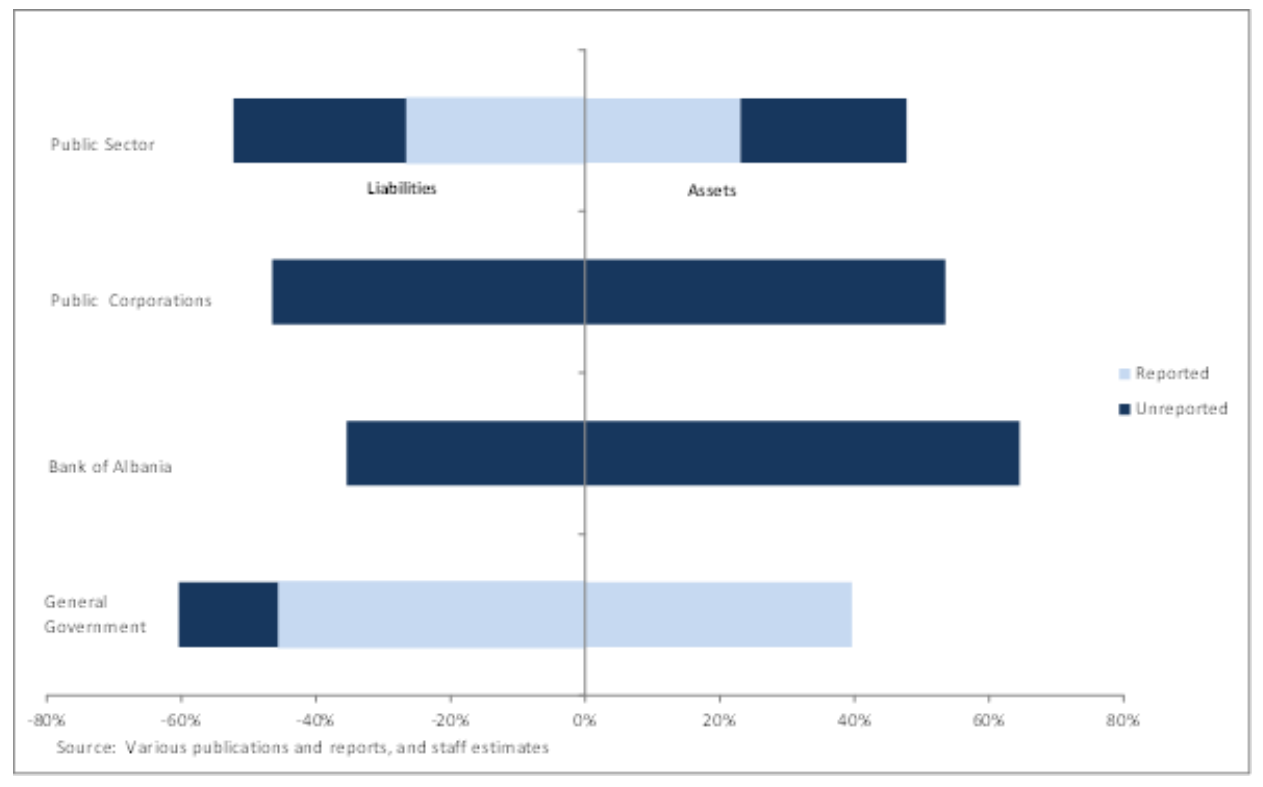

Figure 1.2. Liabilities of the Public Sector, Selected Countries

(Percent of GDP)

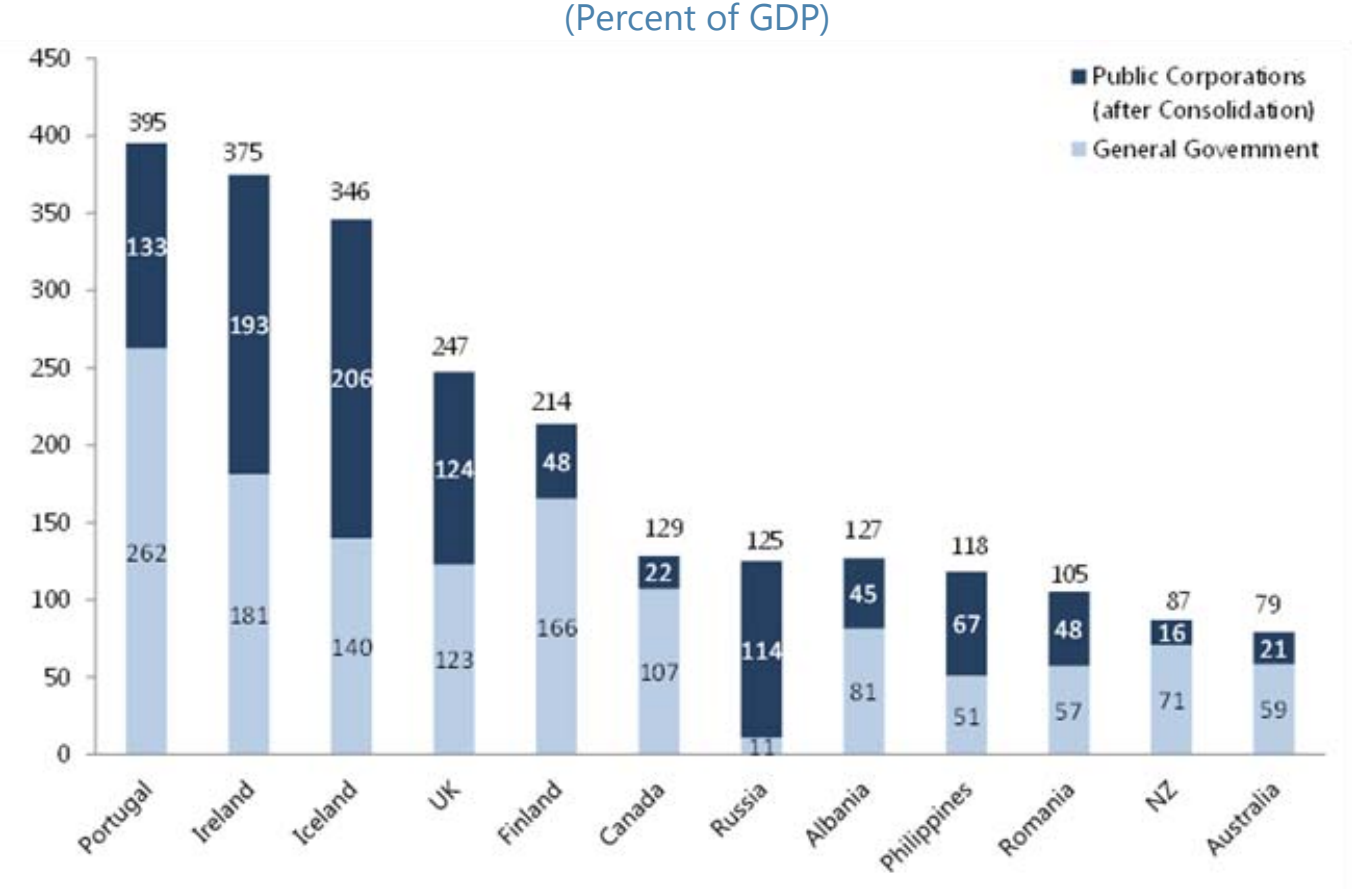

Sources: IMF Staff estimates for Albania, Finland, Portugal, Ireland, Philippines, and Romania, National Financial Statements for other countries, excluding PPP liabilities. 


\subsubsection{Coverage of Stocks (Basic)}

9. Some data on assets and liabilities are available, but the government does not publish its balance sheet. Debt data are published on the Ministry of Finance's website on a quarterly and annual basis. The data do not include accounts payable, however, which are also not reported elsewhere. Data on the government's cash balances are available on the Bank of Albania's website, but not in any government report. No other balance sheet data are routinely published, though individual government entities produce, but do not publish financial statements including a balance sheet. Assets and liabilities related to public-private partnerships are not reported (see

Section 3.2.4); nor are the government's liabilities in relation to the supplementary pension schemes for civil servants, the police, and the military. (International statistical and accounting standards require a liability to be recognized on the government's balance sheet in relation to defined-benefit pension schemes for government employees.) Table 1.4 presents an estimate of the balance sheet of general government for 2013, using available data. Table 1.4 presents an estimate of the balance sheet of general government for 2013, using available data. It includes an estimate for the accrued liability of the civil service pension scheme, based on the present discounted value of all future pension obligations assuming that beneficiaries will continue to increase to a steady state of around 1 percent of the population.

Table 1.4. Albania: Balance Sheet of General Government, 2013

\begin{tabular}{|c|c|c|c|c|c|}
\hline & Billion Lek & Percent of GDP & & Billion Lek & Percent of GDP \\
\hline Assets & 1,132 & 83.0 & $\begin{array}{l}\text { Liabilities } \\
\text { Securities other than Shares }\end{array}$ & 1,131 & 82.9 \\
\hline Nonfinancial Assets & 795 & 58.2 & (Bonds, Treasury Bills) & 552 & 40.4 \\
\hline o/w PPP assets & 96 & 7.0 & Loans & 333 & 24.4 \\
\hline Financial Assets & 337 & 24.7 & Accounts Payable & 131 & 9.6 \\
\hline Currency and Deposits (Cash) & 23 & 1.7 & PPP liabilities & 96 & 7.0 \\
\hline Securities other than Shares (Bonds) & - & - & Pensions & 19 & 1.4 \\
\hline Loans & - & - & & & \\
\hline Equity in Public Corporations & 198.2 & 14.5 & & & \\
\hline Accounts Receivable (Debtors) & 116 & 8.5 & & & \\
\hline Net Financial Worth, & -794 & -58.2 & & & \\
\hline Net Worth & 1 & 0.1 & & & \\
\hline
\end{tabular}

Sources: Bank of Albania and Ministry of Finance's debt reports and draft response to the questionnaire for the IMF's Government Finance Statistics Yearbook, 2014. Eliminations are IMF Staff calculations.

\subsubsection{Coverage of flows (Basic)}

10. Fiscal flows are recorded on a modified cash basis. The financial statements of the general government record the purchase of goods and services on an accrual basis, but revenues and much expenditure, including interest are recorded on a cash basis and no depreciation is charged. Other economic flows resulting from holding gains or changes in the volume of assets and liabilities are not included in fiscal reports. 
11. There are also no reconciliations of fiscal flows with fiscal stocks. For example, the government does not publish a reconciliation of its cash flows during the year with its opening and closing balances. Table 1.5 provides an estimated reconciliation. A reconciliation of the deficit with changes in debt is presented later in the report. Among other things, reconciliations such as these help provide an assurance that flow data are complete.

Table 1.5. Albania: Cash-Flow Reconciliation for General Government, 2013

\begin{tabular}{lrr}
\hline & Billion Lek & Percent of GDP \\
\hline Cash on December 31, 2012 & 15.6 & 1.1 \\
Net cash inflows from operations & 4.7 & 0.3 \\
Net cash inflows from investing & -55.3 & -4.1 \\
Net cash inflows from financing & 58.3 & 4.3 \\
Foreign-currency gains etc. & -0.1 & 0.0 \\
Cash on December 31, 2013 & 23.2 & 1.7 \\
\hline
\end{tabular}

Source: Ministry of Finance, including draft responses to the questionnaire for the IMF's Government Finance Statistics Yearbook, 2014; IMF Staff calculations.

\subsubsection{Coverage of tax expenditures (Not met)}

\section{Albania does not publish an estimate of the revenue loss from tax expenditures.}

Estimates are published of the fiscal impact of some new tax expenditures at the time of presentation of tax laws to Parliament, but there is no systematic reporting of the overall costs of existing and new tax expenditures in budget documents or fiscal reports.

\section{Estimates provided by the Ministry of Finance show exemptions for VAT, excise duty,} and some smaller taxes resulted in revenue loss of 1.2 percent of GDP in 2014 (Table 1.6).

This is not a comprehensive figure, as no data have been provided on expenditures for taxes such as income tax and corporation tax. However, in both these cases the average tax rate in Albania is relatively low, suggesting expenditures are unlikely to be a large source of revenue loss. This suggests that total tax expenditures may not be particularly high by international standards, but further analysis would be needed to confirm this. An OECD report from 2010 found total tax expenditures in several OECD countries were in the range of 5-10 percent of GDP. ${ }^{5}$ Nevertheless, providing full information on all tax expenditures in the budget documents would show which groups and sectors currently benefit from exemptions, and the extent of overall revenue loss, and so improve the transparency of policy-making.

${ }^{5}$ OECD (Organization for Economic Cooperation and Development), Tax Expenditures in OECD Countries, 2010. 


\begin{tabular}{|c|c|c|c|}
\hline \multicolumn{4}{|c|}{$\begin{array}{l}\text { Table 1.6. Value of Tax Expenditures } \\
\text { (Billion Lek) }\end{array}$} \\
\hline & 2012 & 2013 & 2014 \\
\hline Value-Added Tax & 10.3 & 11.0 & 10.4 \\
\hline Excise & 4.9 & 6.7 & 1.1 \\
\hline Minerals & 0.0 & 0.0 & 5.0 \\
\hline Other & 0.8 & 0.3 & 0.3 \\
\hline Total & 16.0 & 18.0 & 16.9 \\
\hline Share of total revenue (\%) & 4.8 & 5.9 & 4.7 \\
\hline Share of GDP (\%) & 1.2 & 1.4 & 1.2 \\
\hline
\end{tabular}

\section{B. Frequency and Timeliness of Fiscal Reporting}

\subsubsection{Frequency of in-year reporting (Advanced)}

14. In-year fiscal reports are frequent and timely. The Ministry of Finance produces monthly fiscal statistics for general government that cover revenues, expenditures, and financing and are generally published on the Ministry's website within 20 days of the end of the month. A quarterly report provides more detailed revenue and expenditure information by budget institution and program. A detailed quarterly report on public debt is also published. The information published on individual daily payments made by the treasury is commendable and adds transparency at a detailed level. ${ }^{6}$

\subsubsection{Timeliness of annual financial statements (Not met)}

15. Fiscal outturns are produced and published in a timely manner, but do not form a set of financial statements. Fiscal outturns are published on the website of the Ministry of Finance in February each year. The law requires that the annual budget-implementation report is produced within five months of the end of the fiscal year, but delays have occurred (the report for 2014 was not published until June). The annual budget-implementation report includes neither a table of the general government outturn against budget nor a table showing budget outturn by ministry and program. As discussed in Section 1.1.2, none of the annual reports include stock information or a cash-flow statement, which would be minimum requirements of financial statements. The audit report-published within 12 months-is in the nature of a compliance report, and the annual fiscal data are not amended as a result of the audit. The government plans to address these weaknesses through adoption of International Public Sector Accounting Standards and through aligning audit approaches to international standards.

\footnotetext{
${ }^{6}$ See this website of the Ministry of Finance, which shows daily payments made through the treasury single account.
} 


\section{Quality of Fiscal Reports}

\subsubsection{Classification (Advanced)}

16. Fiscal reports show detailed information on spending and revenue in line with international standards. Data are published by economic classification in line with the IMF's Government Finance Statistics Manual 2001, by program, and by function according to the United Nations' classification of the functions of government. Revenues are classified according to their type (taxes, social contributions, grants, and other revenue, and with a further breakdown of these). Spending is classified based on administrative, program, functional and economic classifications.

17. Different classifications are, however, shown in different reports. Aggregate data by economic classification compared to budget are available in the reports of both the treasury and the macroeconomic department. The treasury reports also provide actual spending by economic and functional classification, but the latter has no comparison with budget. The quarterly budgetmonitoring report presents budget and outturn information by administrative, economic, and program classification, but not functional classification (see Table 1.1).

\subsubsection{Internal consistency (Basic)}

18. Fiscal reports include one of the reconciliations required by the Fiscal Transparency Code. The reconciliation between the fiscal balance and financing is shown in the monthly, quarterly, and annual reports on fiscal statistics and fiscal indicators. Discrepancies, shown below the line under the heading "other," are significant, and include movements in cash balances in the treasury single account and other accounts, accrual adjustments, onlending, and adjustments to cash for funds held in trust. While a reconciliation of debt issued and debt holdings and of financing and the change in debt is produced, it is not published (Table 1.7). Publishing such a reconciliation would help provide assurance that the government is not engaged in off-budget spending.

\begin{tabular}{|lrr|}
\hline \multicolumn{2}{|c|}{ Table 1.7. Reconciliation of the Deficit With Changes in Debt, 2013} \\
\hline Debt on December 31, 2012 (includes guarantees) & Billion Lek & Percent of GDP \\
Deficit & 828.3 & 60.7 \\
Transactions that affect the deficit but not debt (e.g. bills received but not paid) & 70.4 & -5.6 \\
Changes in in debt caused by exchange-rate movements & -6.0 & -0.4 \\
Change in guaranteed debt (mostly electricity companies) & -2.1 & -0.4 \\
Change in local governments' debt & 0.1 & -0.2 \\
Debt on December 31, 2013 & 885.1 \\
\hline $\begin{array}{l}\text { Source: Ministry of Finance, including draft responses to the questionnaire for the IMF's Government Finance Statistics Yearbook, } \\
\text { 2014; IMF Staff calculations. }\end{array}$ \\
\hline
\end{tabular}




\subsubsection{Historical revisions (Not met)}

19. Fiscal statistics are not revised. For submissions to the IMF's Government Finance Statistics Yearbook, for example, the government submits only the latest year in each submission; no revisions are made.

\section{Integrity of Fiscal Reports}

\subsubsection{Statistical integrity (Not met)}

20. Fiscal statistics are compiled and disseminated by the Institute of Statistics (INSTAT), but do not fully meet international and European Union requirements. In addition to compiling some government finance statistics according to national standards, INSTAT compiles debt published on the IMF-World Bank online database, following the Public Sector Debt Statistics Guide for Compilers and Users. However, many gaps in the data exist, and neither INSTAT nor the Ministry of Finance produces a full submission to Eurostat. INSTAT is a professional agency, and its responsibilities for the collection, compilation, and dissemination of statistics are clearly defined by Law 9180 of 2004. Nevertheless, INSTAT appears to lack sufficient legal safeguards and technical capacity to make it truly independent. ${ }^{7}$

\subsubsection{External audit (Basic)}

\section{The independent Supreme State Audit publishes an annual report on the} implementation of the budget, but does not issue an opinion. It audits the report on implementation of the budget, the annual report on public debt, and the individual statements of selected entities with over 50 percent state ownership. Audit coverage is limited: for 2013, only 124 out of 1,469 entities (8 percent, approximately 40 percent of budget spending) were audited, including a risk-based sample of ministries, departments, agencies, local governments, projects, and public enterprises. However, there is currently no certification or audit opinion on the individual financial statements of central or local budget institutions or on the consolidated fiscal statement. A new law on the organization and functioning of the supreme audit institution (Law 154 of 2014) was passed in February 2015, which gives authority for the institution to issue an opinion on the annual financial statements of general government units and the annual report on implementation of the budget. The Chairman of the Supreme State Audit is appointed by Parliament and can only be removed on recommendation of the President under specified circumstances, the office has access to all records and discretion to plan and execute audits. The Supreme State Audit is a member of the International Organization of Supreme Audit Institutions and is gradually moving toward operating in accordance with international audit standards.

\footnotetext{
${ }^{7}$ See European Commission, Albania: Progress Report, 2014, p. 35.
} 


\subsubsection{Comparability of fiscal data (Basic)}

22. Fiscal reports are comparable with the budget. The monthly fiscal statistics (budget outturns) are prepared and published on the same basis as the budget, as is the annual fiscal table. Published fiscal statistics do not differ from other fiscal data. Since there are no differences, there is no need for reconciliation. Producing fiscal statistics that follow all European (and IMF) standards will, however, require several changes that will cause them to differ from budget outturns. For example, the statistics will need to cover various entities that are outside the budget but are deemed to be part of general government (see Section 1.1.1). These changes will create a need for reconciliations between the budget deficit and the deficit in fiscal statistics.

\section{E. Conclusions and Recommendations}

23. Table 1.8 summarizes the assessment of Albania's practices against the Code. It shows that in some areas Albania meets the standard of advanced or good practice, particularly in the coverage, frequency, and classification of data. It also shows that improvements are needed in several areas, particularly in the reporting of stocks-including accounts payable and liabilities related to public-private partnerships and civil-service pensions-and of tax expenditures. The integrity of reports could be further improved by publishing reconciliations between stocks and flows, requiring an audit opinion on annual financial statements, and making INSTAT fully independent. The following recommendations are designed to address these issues.

24. Recommendation 1.1: Balance sheet and stock-flow reconciliations. Gradually develop a balance sheet for the public sector that is integrated with reports on revenue and spending:

- $\quad$ Publish reconciliations of changes in cash balances with cash flows and changes in debt with the deficit in advance of a move to full accrual accounting.

- $\quad$ Publish a balance sheet for the general government, starting with financial assets and liabilities (initially, cash, advances, accounts payable, and debt).

- $\quad$ Progressively expand the balance sheet to include all financial and nonfinancial assets and liabilities, including those related to pensions and public-private partnerships.

25. Recommendation 1.2: Rationalization of reports. Reduce the duplication of information in fiscal reports by publishing one definitive set of monthly, quarterly, and annual data, crossreferenced to supporting information.

26. Recommendation 1.3: Tax expenditures. Publish every year an estimate of revenue foregone from tax expenditures by type. 
Table 1.8. Summary Evaluation of Albania's Fiscal Reporting

\begin{tabular}{|c|c|c|c|c|}
\hline & Principle & Assessment & Importance & Rec. \\
\hline 1.1.1 & $\begin{array}{l}\text { Coverage of } \\
\text { Institutions }\end{array}$ & $\begin{array}{l}\text { Basic: Published fiscal reports } \\
\text { consolidate most of general } \\
\text { government, with some } 27 \text { entities } \\
\text { excluded, but not the public sector. }\end{array}$ & $\begin{array}{l}\text { Medium: Missing parts of general } \\
\text { government appear small; public } \\
\text { corporations including central bank } \\
\text { add non-equity liabilities of about } 33 \\
\text { percent of GDP. }\end{array}$ & \\
\hline 1.1 .2 & $\begin{array}{l}\text { Coverage of } \\
\text { Stocks }\end{array}$ & $\begin{array}{l}\text { Basic: Debt is reported by the Ministry } \\
\text { of Finance and cash by the Bank of } \\
\text { Albania; other financial assets and } \\
\text { liabilities are not reported. }\end{array}$ & $\begin{array}{l}\text { High: General government } \\
\text { unreported, civil service pensions, PPPs } \\
\text { and accounts payable for } 2013 \text { are } \\
\text { estimated at } 9.6 \text { percent GDP. }\end{array}$ & 1.1 \\
\hline 1.1.3 & Coverage of Flows & $\begin{array}{l}\text { Basic: Many fiscal reports show cash } \\
\text { revenues, near-cash expenditures, and } \\
\text { financing; separate cash and accrual } \\
\text { data are not published. }\end{array}$ & $\begin{array}{l}\text { Medium: Fuller data on fiscal flows } \\
\text { will help in reconciling them with } \\
\text { stocks and meeting international } \\
\text { statistical standards (GFSM } \\
\text { 2014/ESA2010). }\end{array}$ & 1.2 \\
\hline 1.1.4 & Tax Expenditures & $\begin{array}{l}\text { Not Met: Estimates are made of the } \\
\text { cost of exemptions when laws are } \\
\text { passed, but there is no annual report on } \\
\text { total tax expenditure. }\end{array}$ & $\begin{array}{l}\text { Medium: Revenue loss from tax } \\
\text { expenditures was at least } 1.2 \text { percent } \\
\text { of GDP in } 2014 \text {. }\end{array}$ & 1.3 \\
\hline 1.2 .1 & $\begin{array}{l}\text { Frequency of In- } \\
\text { year Fiscal } \\
\text { Reports }\end{array}$ & $\begin{array}{l}\text { Advanced: Cash-based budget- } \\
\text { execution reports are published } \\
\text { monthly, with a lag of less than a month. }\end{array}$ & $\begin{array}{l}\text { Low: Fiscal outturns are published } \\
\text { within } 20 \text { days. }\end{array}$ & \\
\hline 1.2 .2 & $\begin{array}{l}\text { Timeliness of } \\
\text { Annual Financial } \\
\text { Statements }\end{array}$ & $\begin{array}{l}\text { Not met. The report on implementation } \\
\text { of the budget is published/within } 6 \\
\text { months of the end of the fiscal year, but } \\
\text { does not include financial statements }\end{array}$ & $\begin{array}{l}\text { High: The Budget implementation } \\
\text { report should include the financial } \\
\text { statements. . }\end{array}$ & \\
\hline 1.3.1 & Classification & $\begin{array}{l}\text { Advanced: Fiscal reports include } \\
\text { administrative, functional, program, and } \\
\text { economic classifications consistent with } \\
\text { international standards. }\end{array}$ & $\begin{array}{l}\text { Low: Information is available but } \\
\text { scattered among different } \\
\text { publications. }\end{array}$ & \\
\hline 1.3.2 & $\begin{array}{l}\text { Internal } \\
\text { Consistency }\end{array}$ & $\begin{array}{l}\text { Basic: Fiscal reports reconcile the deficit } \\
\text { with financing, but not with changes in } \\
\text { debt. }\end{array}$ & $\begin{array}{l}\text { High. Unexplained changes in debt } \\
\text { stock were -1 percent and } 1.5 \text { percent } \\
\text { GDP in } 2013 \text { and } 2014 \text {. }\end{array}$ & 1.1 \\
\hline 1.3.3 & $\begin{array}{l}\text { Historical } \\
\text { Consistency }\end{array}$ & Not met: Fiscal statistics are not revised. & $\begin{array}{l}\text { Low: Revisions are valuable, but the } \\
\text { priority is to prepare comprehensive } \\
\text { and robust fiscal statistics. }\end{array}$ & \\
\hline 1.4.1 & $\begin{array}{l}\text { Statistical } \\
\text { Integrity }\end{array}$ & $\begin{array}{l}\text { Not Met: Fiscal statistics are } \\
\text { disseminated but do not yet meet } \\
\text { international standards. }\end{array}$ & $\begin{array}{l}\text { Medium: Meeting EU standards will } \\
\text { require stronger safeguards of the } \\
\text { integrity of reporting. }\end{array}$ & \\
\hline 1.4 .2 & External audit & $\begin{array}{l}\text { Basic: An independent supreme audit } \\
\text { institution publishes a report on } \\
\text { implementation of the budget, based on } \\
\text { a limited audit sample, but not an } \\
\text { opinion. }\end{array}$ & $\begin{array}{l}\text { High: Only } 8 \text { percent of entities were } \\
\text { subject to audit in } 2013 \text {. }\end{array}$ & \\
\hline 1.4 .3 & $\begin{array}{l}\text { Comparability of } \\
\text { fiscal data }\end{array}$ & $\begin{array}{l}\text { Basic: Budget-execution reports are } \\
\text { prepared on the same basis as the } \\
\text { budget. (Fiscal statistics or financial } \\
\text { statements different from budget- } \\
\text { execution reports have not yet been } \\
\text { published). }\end{array}$ & $\begin{array}{l}\text { Medium: Reconciliations will become } \\
\text { important in the future, when there are } \\
\text { differences between budget outturns } \\
\text { and fiscal statistics. }\end{array}$ & \\
\hline
\end{tabular}




\section{FISCAL FORECASTING AND BUDGETING}

\section{This section assesses the quality of fiscal forecasting and budgeting practices relative} to standards set by the IMF's Fiscal Transparency Code. It focuses on four main areas:

- The comprehensiveness of the budget and associated documentation;

- The orderliness and timeliness of the budget process;

- The policy orientation of budget documentation; and

- $\quad$ The credibility of the fiscal forecasts and budget proposals.

28. Albania's fiscal forecasting and budgeting practices meet advanced or good standards in several areas. The annual budget is regulated by comprehensive fiscal legislation. The government produces regular medium-term macroeconomic and fiscal forecasts and sets out medium-term expenditure plans on a ministry and program basis. This information is provided to parliament and published in a full set of budget documents (Table 2.1). The annual budget process is typically completed on a timely basis with approval by parliament before the start of the fiscal year.

29. However, there is scope for significantly improving the credibility of fiscal forecasting and budgeting. Over recent years, budget-year and medium-term revenue projections have been consistently optimistic. As a result, the medium-term expenditure projections have not provided a reliable guide for planning, and the approved budget has often been reduced significantly during the year, undermining the credibility of the budget process. The government's forecasts are not compared to those of external forecasters, subject to independent evaluation, or assessed for accuracy. Furthermore, little explanation is provided of the factors causing changes compared to previous forecasts and plans-in particular, the impact of new budget policy decisions on the public finances is not systematically quantified or explained. Limited information is provided on obligations under multi-annual investment projects and there are weaknesses in project appraisal and implementation.

30. There are also shortcomings in the policy orientation of the budget. The government does not clearly state and report on fiscal objectives to guide policy-making. Public participation in the budget is limited, and no accessible summary of the implications of budget policy decisions is produced. Detailed performance objectives and targets for ministries and policy programs are specified and monitored, but have limited influence on policy-making. 
Table 2.1. Albania: Fiscal Forecasting and Budget Documents

\begin{tabular}{|c|c|c|}
\hline Document & Content & Timing \\
\hline $\begin{array}{l}\text { National Economic Reform Program } \\
\text { (previously Economic and Fiscal } \\
\text { Program) }\end{array}$ & $\begin{array}{c}\text { Report to the EU providing detailed three-year } \\
\text { macroeconomic and fiscal analysis and forecasts and } \\
\text { medium-term economic strategy }\end{array}$ & January \\
\hline Macroeconomic and Fiscal Framework & $\begin{array}{l}\text { Summary of government's three-year medium-term } \\
\text { macroeconomic and fiscal forecasts }\end{array}$ & January \\
\hline Medium-Term Budget Program & $\begin{array}{l}\text { Summary of government's three-year medium-term } \\
\text { macroeconomic and fiscal forecasts and expenditure } \\
\text { and outcomes plan by program and ministry }\end{array}$ & $\begin{array}{l}\text { First draft in Spring. } \\
\text { Final draft published } \\
\text { after budget } \\
\text { approval }\end{array}$ \\
\hline Budget Law and accompanying tables & $\begin{array}{l}\text { Final aggregate budget revenue, expenditure, and } \\
\text { financing tables }\end{array}$ & October/November \\
\hline Report on the Budget Law & $\begin{array}{c}\text { Assessment of outturn in the year-to-date, } \\
\text { discussion of main new budget policies and } \\
\text { expenditure allocations }\end{array}$ & October/November \\
\hline $\begin{array}{l}\text { Ministry of Finance Monitoring } \\
\text { Reports }\end{array}$ & $\begin{array}{l}\text { Quarterly and annual reports on expenditure and } \\
\text { outcomes compared to budget by ministry and } \\
\text { program }\end{array}$ & $\begin{array}{l}\text { Quarterly and } \\
\text { Annual }\end{array}$ \\
\hline Economy and Budget & $\begin{array}{l}\text { Monthly report on the performance of the economy } \\
\text { and key fiscal statistics }\end{array}$ & Monthly \\
\hline Economy in Focus & $\begin{array}{l}\text { Monthly summary of key economic and fiscal } \\
\text { indicators }\end{array}$ & Monthly \\
\hline Annual Macroeconomic Indicators & $\begin{array}{l}\text { Annual summary of key economic and fiscal } \\
\text { indicators }\end{array}$ & Annual \\
\hline
\end{tabular}

\section{A. Comprehensiveness}

\subsubsection{Budget unity (Basic)}

31. Budget documentation excludes the revenues, expenditures, and financing of several central government entities. The 2008 Law on the Management of the Budgetary System defines the state budget to include all revenues, expenditures, and financing of the central government (Article 5). Article 7 of the law provides for the establishment of extrabudgetary or "special" funds of central government, and requires that their budgets are presented and approved with the state budget. $^{8}$ The revenues, expenditure, and financing of local government are also presented in the state budget. However, as discussed in Section 1.1.1, there are several entities that should be added to central government according to statistical rules, and are not currently covered in the budget. Further, the financing of loss-making public corporations is not fully covered. For example, guarantees provided to electricity companies have not been included in the budget tables, despite the gross exposure being included in the calculation of gross debt. Debt-financed investment in the

\footnotetext{
${ }^{8}$ Three special funds have been established and are included in the budget: a social-security (pensions) fund, a health-insurance fund, and an infrastructure-compensation fund. The financing and expenditure of a further fund established in law as a nonprofit organization, the Albania Development Fund, is also included.
} 
electricity sector is also not included, despite also being included in gross debt. These issues make it difficult to reconcile changes in the debt stock with the flows shown in the budget tables (for wider discussion of the reconciliation of debt stock with flows see Section 1.3.2).

32. All revenues and expenditures are reported in the budget on a gross basis, as required by Articles 5, 6, and 7 of the budgetary system law. Revenues collected directly by ministries and agencies amounted to around 17 percent of gross expenditures in 2015. As shown in Figure 2.1 this is in line with levels seen in other countries surveyed. The bulk of these revenues are accounted for by contributions to the social security fund, which were expected to amount to around 12 percent of gross expenditures in 2015.

Figure 2.1. Social Security Contributions and Own-Source Revenues, Selected Countries (2010-15, Percent of gross expenditure)

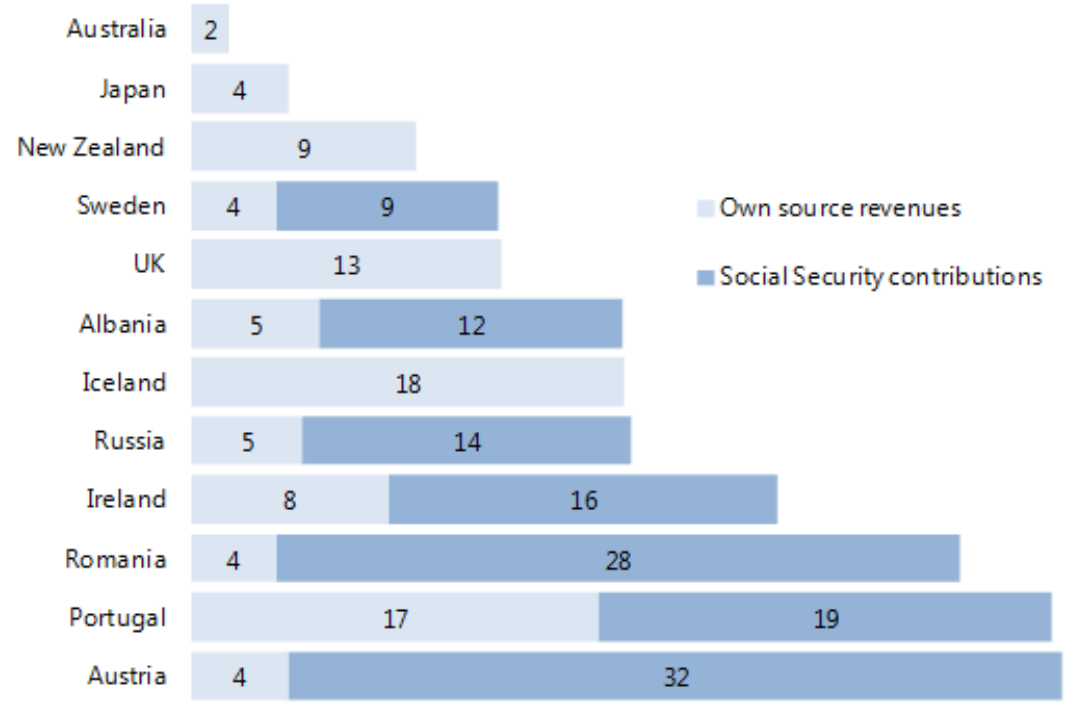

Sources: Albania: Medium-Term Budget Program 2014; Other countries: National documents; IMF staff calculations.

\subsubsection{Macroeconomic forecasts (Advanced)}

33. Albania produces detailed medium-term macroeconomic forecasts that are intended to underpin budget planning. Three-year forecasts are produced of the key macroeconomic variables, their components, and the underlying economic assumptions. Summary forecast tables are published in the Macroeconomic and Fiscal Framework in January each year at the start of the medium-term budget process. A detailed explanation of economic performance and the assumptions underlying the forecast is set out in the National Economic Reform Program, provided to the EU in January each year. The forecast and a summary explanation are also set out in the Medium-Term Budget Program (MTBP), which is provided in draft to the Council of Ministers alongside the draft budget law and is then updated and published after the final budget has been approved. 


\section{Over the past decade, budget-year and medium-term GDP forecasts have been} consistently optimistic (Figure 2.2). In particular, since the downturn in 2009, successive forecasts have predicted a recovery in growth rates that did not materialize. As shown in Figure 2.3, between 2002 and 2012, Albania's GDP forecast errors were large in comparison to EU member states.

Budget-year forecast errors averaged -1.5 percentage points, which was the second largest among the countries shown, while errors for one and two years out were also relatively large at -2.2 percentage points and -2.5 percentage points, respectively. This is despite the fact that, as shown in Section 3.1.1, GDP volatility in Albania has been low compared to countries in the region. Further discussion of the credibility of the macroeconomic forecasts is provided in Sections 2.4.1 and 2.4.3.

Figure 2.2. Forecasts and Outturn for Real GDP Growth

(Percent)

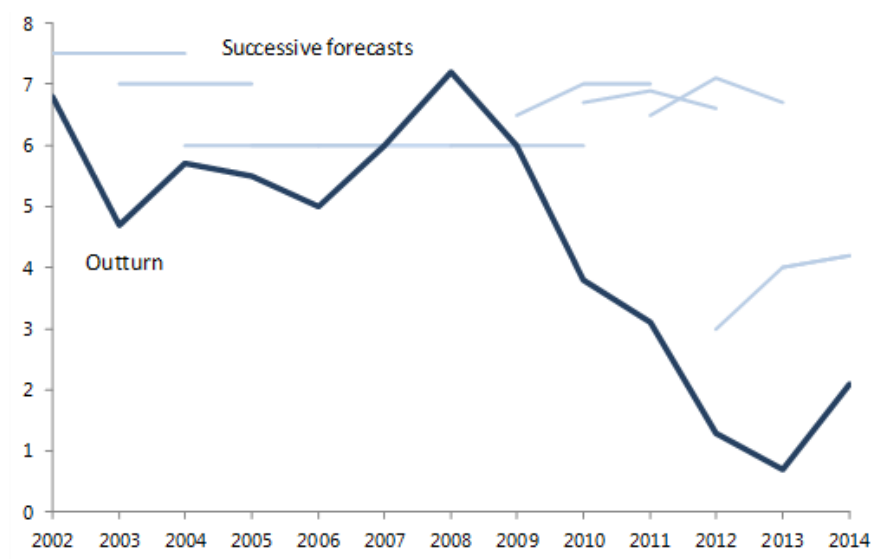

Figure 2.3. Average Forecast Errors for Real GDP Growth, Albania and EU countries

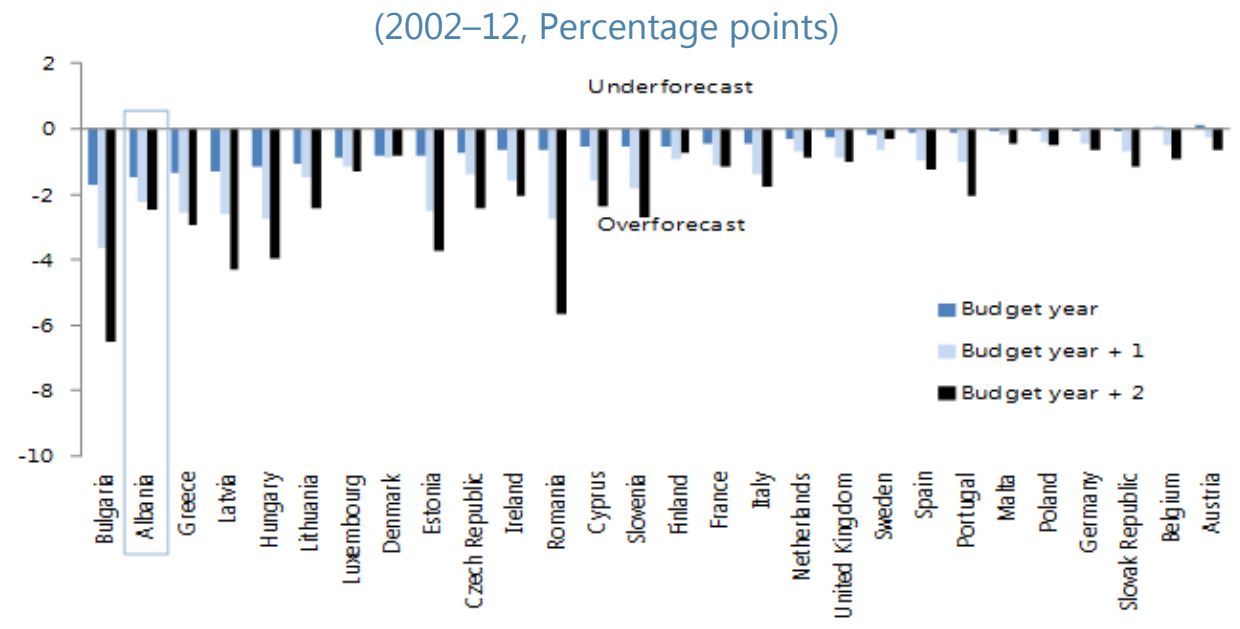

Sources: IMF staff calculations; Eurostat; Medium-Term Budget Program.

Note: Countries are ordered by the size of budget-year errors. The EU includes a number of high-income countries whose forecasting practices would meet "advanced" practice under the Code. However, it is an appropriate group for comparison given Albania's EU candidate-country status. 


\subsubsection{Medium-term budget framework (Good)}

35. Albania introduced a medium-term budget framework in $\mathbf{2 0 0 0}$ based on three-year fiscal projections and expenditure plans on a ministry and program basis. The plans are set out in the MTBP, which provides three-year projections of revenues, expenditures, and financing by economic category and by ministry and program, and two years of outturn data by economic category. Annual data on outturns for individual ministries and programs are provided separately in budget-monitoring reports, but no historical series is published. The MTBP is approved by a Strategic Planning Committee chaired by the Deputy Prime Minister before being submitted to the Council of Ministers. Subsequently the MTBP is submitted to Parliament alongside the main budget. In 2014, the MTBP was for the first time approved by Parliament alongside the Budget Law. This is intended to strengthen the role of the outer-year ceilings in budget policy-making and planning. Previously the outer-year ceilings were seen as purely indicative and were often adjusted significantly between successive MTBPs.

\section{The credibility of the medium-term budget framework has been undermined by} consistently optimistic revenue forecasts. As shown in Figure 2.4, during the period 2002-12, Albania's average medium-term revenue forecast errors were among the highest among the EU member and candidate countries. These errors are likely in large part to have been caused by the optimism of the GDP forecasts, as discussed in Sections 2.1.1 and 2.3.3. As a result, the expenditure projections set out in the MTBP have proved an unreliable basis for planning. Final outturn has been significantly lower on average than the projections made in the medium-term framework (Figure 2.5).

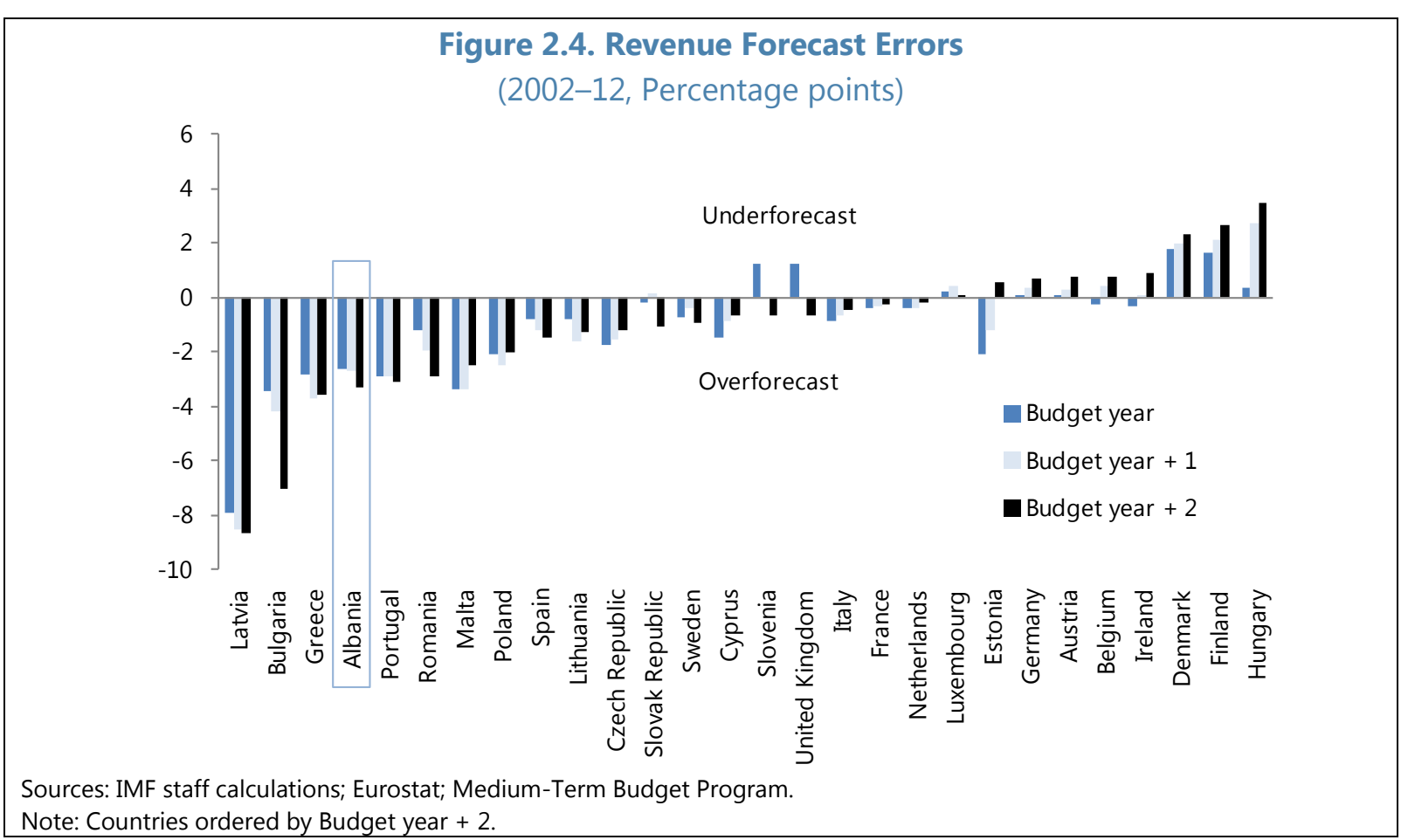


Figure 2.5. Difference Between Expenditure Projections and Outturns

(2002-12, Percentage points)

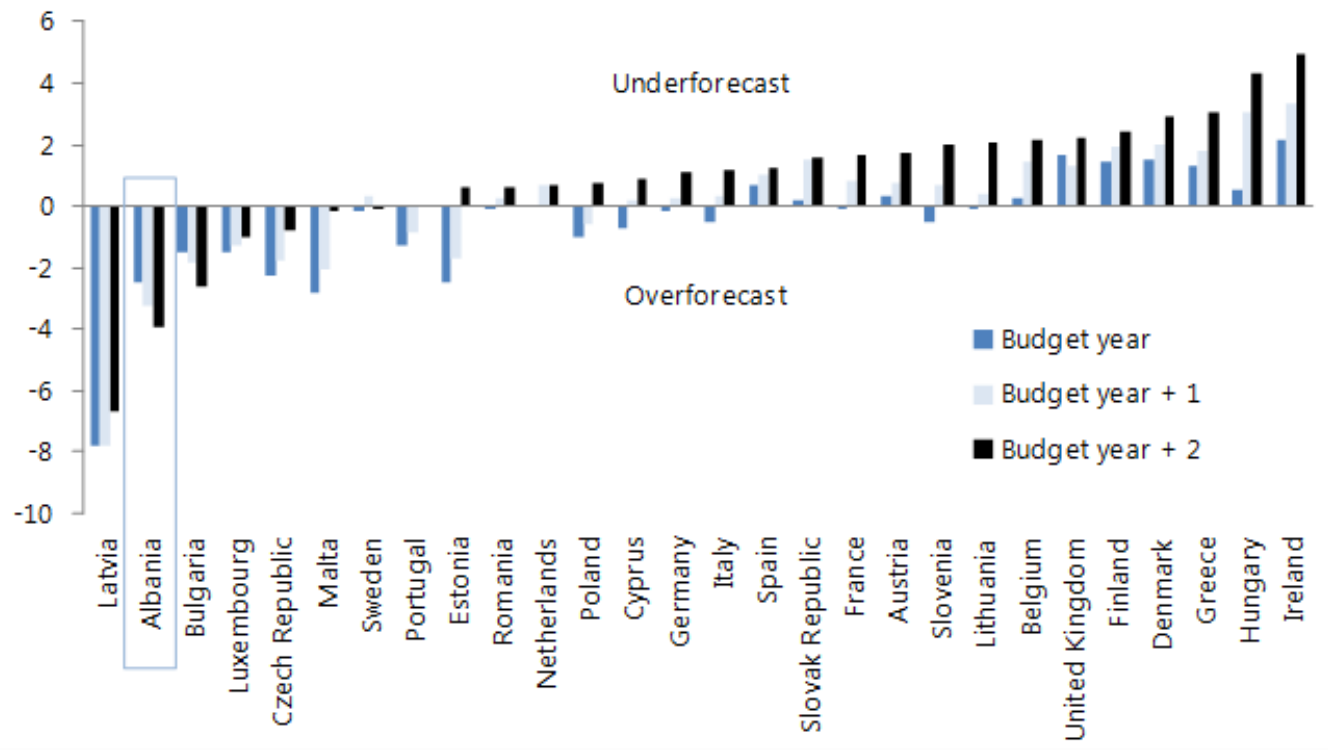

Sources: IMF staff calculations; Eurostat; Medium-Term Budget Program.

Note: Countries ordered by Budget year +2 .

\subsubsection{Investment projects (Not met)}

\section{Limited information is provided on financial obligations under multi-annual}

investment projects. The MTBP includes the objectives and expected outputs of each investment project and the estimated expenditure in the current year and over the three-year planning horizon. However, no estimate is provided of the full value of obligations for each project, despite this being required by Article 29 of the budgetary system law, or of the overall total obligations for all projects. As set out in Section 3.2.4, there is also very little reporting of investment projects financed as public-private partnerships. The government acknowledges in its Public Finance Management Strategy 2014-20 that multi-annual project controls are weak, with ministries entering into contracts without accounting for the impact on future years' budgets, and it is considering reforms to address this issue. It has already introduced a new treasury approval process for multi-annual commitments.

38. There are also weaknesses in project appraisal, selection, and implementation. Costbenefit analysis is undertaken for major projects, but the results are not published. The law on public procurement requires that all major projects should be contracted via open and competitive tender, but this has not been the case for two very large projects-part of the Durrës to Kukës road and the new Arbëri road-which were implemented through specific pieces of legislation that overrode the standard tender process.

39. Government investment spending has been relatively high over the past decade, reflecting the country's infrastructure and development needs (Figure 2.6). This is despite the fact that capital spending has been typically reduced significantly compared to the original medium- 
term and annual plans set out in the budget. As set out in Section 2.1.3, expenditure projections have been consistently higher than final outturn in Albania. Figure 2.7 shows that capital spending outturns have been on average 30 percent lower than plans set three years ahead, and 17 percent lower than in the annual budget. This probably reflects the fact that capital spending is often easier to reduce than current spending in the face of shortfalls of revenue against forecast.

Figure 2.6. Gross Capital Expenditure of General Government, EU and Selected Countries (2002-13, Percent of GDP)

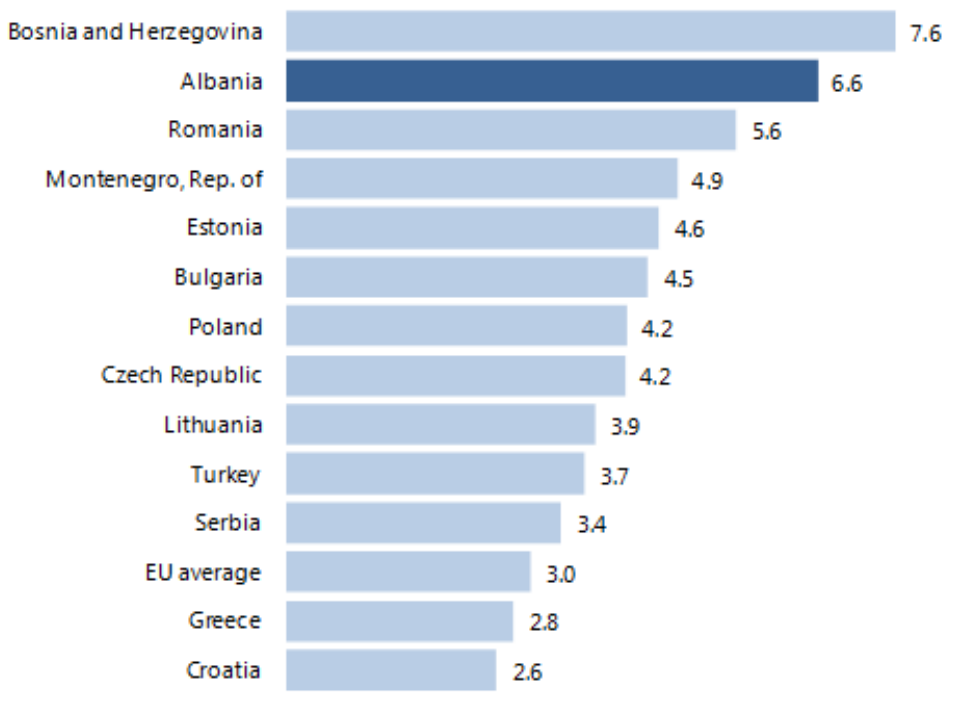

Figure 2.7. Albania: Difference Between Expenditure Plans and Outturn

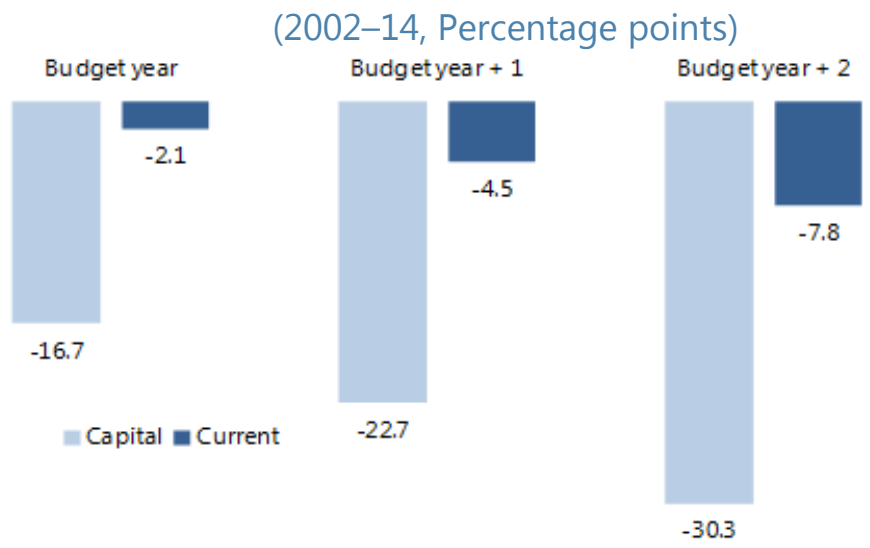

Source: IMF staff calculations; Eurostat; Medium-Term Budget Program. 


\section{B. Orderliness}

\subsubsection{Fiscal legislation (Advanced)}

40. Albania has a comprehensive legal framework covering budget preparation and approval and the key contents of budget documentation. The 1998 Constitution sets out key provisions for the public finances, such as a framework of state and local budgets and the broad powers of the executive and the legislature. The Law on the Management of the Budgetary System establishes, among other things, the system of budgeting, the roles and responsibilities of the main stakeholders, the process for budget preparation, analysis, and approval (including the required contents of budget documents), the budget implementation process, authority to borrow and issue guarantees, and accounting and auditing practices. There are also laws on local government, debt management, public procurement, audit, and tax administration. ${ }^{9}$

\section{The Law on the Management of the Budgetary System does not place restrictions on} the legislature's constitutional power to amend the budget, which is therefore without limit. The constitution states that parliament must approve the budget and also that it may amend the budget during the year (Articles 158 and 160). The budgetary system law sets out the timetable for parliament to approve the budget and procedures for the provision of an interim budget if approval has not been granted within this timetable (Articles 30, 35, and 36). It also sets out procedures for making in-year amendments to the budget (discussed further in Section 2.4.2). However, there are no procedures establishing the extent to which parliament may amend the budget, which, given the broad power to amend provided under the constitution, is therefore without limit. As set out in Section 2.4.2, in recent years the government has used wider legislative procedures to bypass the standard approval process for in-year budget changes.

\subsubsection{Timeliness of budget documents (Good)}

\section{The budgetary system law requires the draft budget to be submitted at least two} months before the start of the fiscal year and approved by the start of the fiscal year. As shown in Table 2.2, in general in recent years these deadlines have been adhered to, with the major exception of the submission of the draft budget for 2014, which was delayed by a general election in June 2013. The draft and final budget documents are made available to the public on the Ministry of Finance website at the same time as they are submitted and approved.

\footnotetext{
${ }^{9}$ A full list of related laws is provided in: Albania - Public Economic Financial Accountability Assessment 2011, January 2012, p. 22.
} 
Table 2.2. Albania: Dates of Budget Submission and Approval

\begin{tabular}{|c|c|c|c|c|c|}
\hline Budget year & $\mathbf{2 0 1 1}$ & $\mathbf{2 0 1 2}$ & $\mathbf{2 0 1 3}$ & $\mathbf{2 0 1 4}$ & $\mathbf{2 0 1 5}$ \\
\hline Budget submitted & Oct. 29 & Oct. 31 & Oct. 30 & Dec. $15^{*}$ & Nov. 3 \\
\hline Budget approved & Nov. 26 & Dec. 2 & Dec. 17 & Dec. 28 & Nov. 27 \\
\hline
\end{tabular}

Sources: National budget documents.

Note: * submitted late due to general election in June 2013. The new government was not sworn in until September 2013.

\section{Policy Orientation}

\subsubsection{Fiscal policy objectives (Not met)}

43. Currently the government does not report on clear and measureable objectives for the public finances. In 2012, the government abolished a debt ceiling of 60 percent of GDP, which had served as its fiscal objective since 2008. An objective of reducing debt to 65.5 percent of GDP is mentioned in the 2014 report on the Budget Law, but this does not appear in other budget documents and there is no regular reporting on progress toward achieving it. For example, it does not consistently appear in the MTBP or the Macroeconomic and Fiscal Framework, both of which are intended to set the fiscal framework within which budget policy decisions are taken.

\section{The government has stated that it intends to introduce a fiscal rule at the end of the} current IMF-supported program. By 2015 it intends to establish fiscal rules "that will guide fiscal policy toward long-term sustainability of public debt, leaving reasonable room for counter-cyclical policy." 10

\subsubsection{Performance information (Advanced)}

45. The MTBP provides very detailed targets for the outcomes and outputs to be achieved under each of around $\mathbf{1 0 0}$ policy programs. Objectives are set at three levels: ministry, program, and output. The MTBP sets out the overall policy objective of each ministry, outcome and output targets, and the programs that will contribute to meeting those targets. Each program then has a number of specific targets specified for each year. Each program is further divided into several outputs, which each have specified objectives, output targets, and expenditure allocations for the medium term. Implementation of budgeted expenditure and discussion of performance against these targets is reported in quarterly monitoring reports published on the Ministry of Finance's website for each ministry, and on an annual basis in the Report on the Implementation of the Budget.

46. While the performance information and framework meets the advanced requirements of the Code, in practice it plays a limited role in policy making or improving public services. The very large number of targets at the program and output level limits their value in providing strategic direction for policy or in scrutinizing the performance of ministries. While monitoring

\footnotetext{
${ }^{10}$ National Economic Reform Programme 2015-17, p. 46. See also Public Finance Management Strategy 2014-20.
} 
reports are produced, ministries have not been systematically held accountable for shortfalls against performance targets. Moreover, as set out in Section 2.1.3, the medium-term plans have not been realistic in the past which undermines the credibility of the process.

\subsubsection{Public participation (Not met)}

47. The government does not produce an accessible summary of the budget for citizens, and there are few opportunities for the public to participate in budget deliberations. The government's Public Finance Management Strategy 2014-20 states that it will prepare a simplified citizens' budget in 2015. The Open Budget Survey 2012 of Albania finds that opportunities for public participation in the budget process are limited. It reports that there are no mechanisms for consultation or feedback with the public by the executive, and only limited opportunities for the public to participate in budget scrutiny and approval by the legislature.

\section{Credibility}

\subsubsection{Independent evaluation (Not met)}

48. The government's economic and fiscal forecasts are not subject to independent evaluation or compared with those of independent forecasters. As set out in Sections 2.1.2 and 2.1.3, consistently optimistic macroeconomic and revenue forecasts have undermined the credibility of Albania's medium-term budget framework. The government's Public Finance Management Strategy 2014-20 identifies options for addressing this issue, including setting up an independent fiscal council to either produce or assess the forecasts, or obliging the government to use an average of the forecasts produced by the central bank and international organizations.

\subsubsection{Supplementary budget (Basic)}

49. The Law on the Management of the Budgetary System sets out procedures governing in-year changes to the budget, but changes have been made without prior approval by the Parliament. The law allows two types of changes to be made without the prior approval of Parliament. First, under Article 44 reallocations of funds can be made between programs, up to 10 percent of the total funds approved for the program, while reallocation of funds can be made within programs with no limit. Second, under Article 45 supplementary funds can be made available for unforeseen expenditures from a reserve fund. The budget has also included a smaller contingency reserve which can be released if revenue forecasts are realized (Section 3.2.1). Under Article 46, additional changes require the Annual Budget Law to be amended, which requires the approval of Parliament. However, in recent years, the government has used a procedure established in the constitution, known as a "Normative Act," to make in-year changes to the budget that only require ex post approval by Parliament within 45 days.

50. Using one or more of these procedures there have been significant changes to the approved budget in recent years, typically in response to shortfalls in revenue. Figure 2.8 shows that since 2002 the final expenditure outturn has often been significantly lower than the 
submitted budget. Typically only small amendments have been made to the submitted budget before its approval by parliament. However, there have often been significant reductions to expenditure allocations in the approved budget during the year through supplementary budgets. There has also often been a significant expenditure shortfall between the supplementary budget and final outturn. In the most recent two years, this has been due to the use of Normative Acts. In other cases, it has been due to shortfalls in the execution of the budget during the year. As shown in Figure 2.9, the reduction in spending compared to the submitted budget is large by international standards.

Figure 2.8. Albania: Changes to the Submitted Budget

\section{(Percent)}

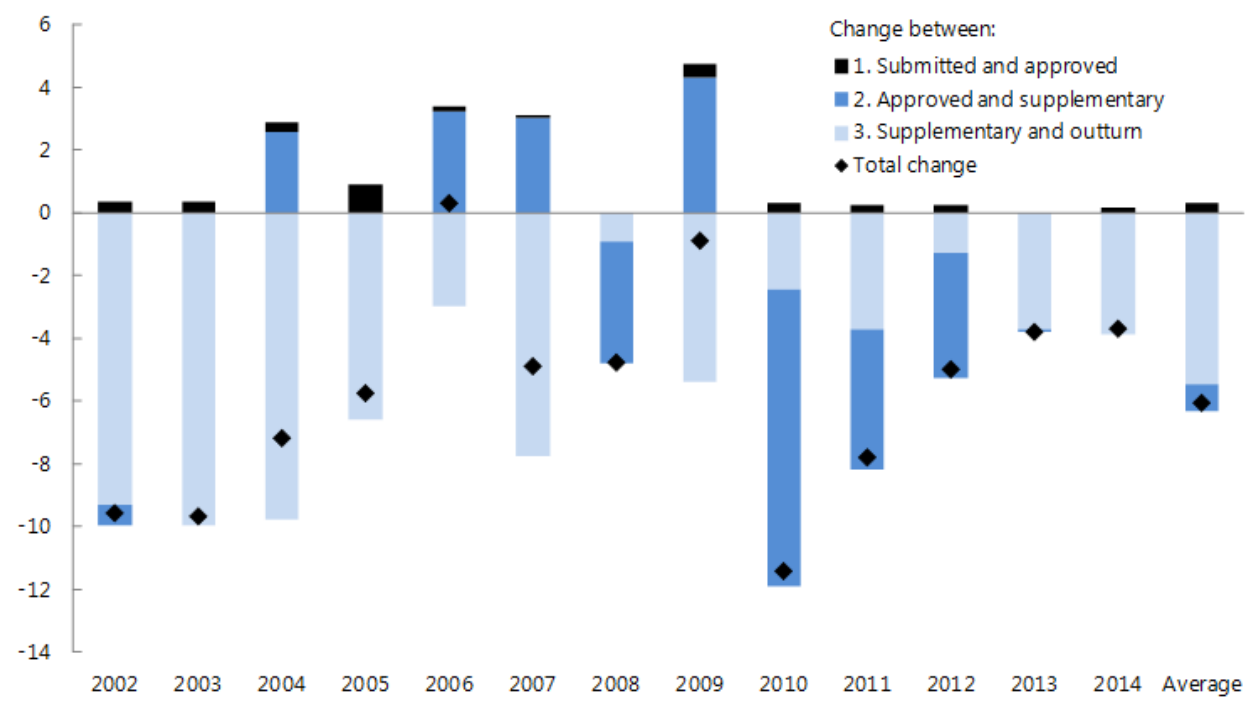

Figure 2.9. Difference Between Submitted Budget and Outturn in Selected Countries (2008-12, Percent)

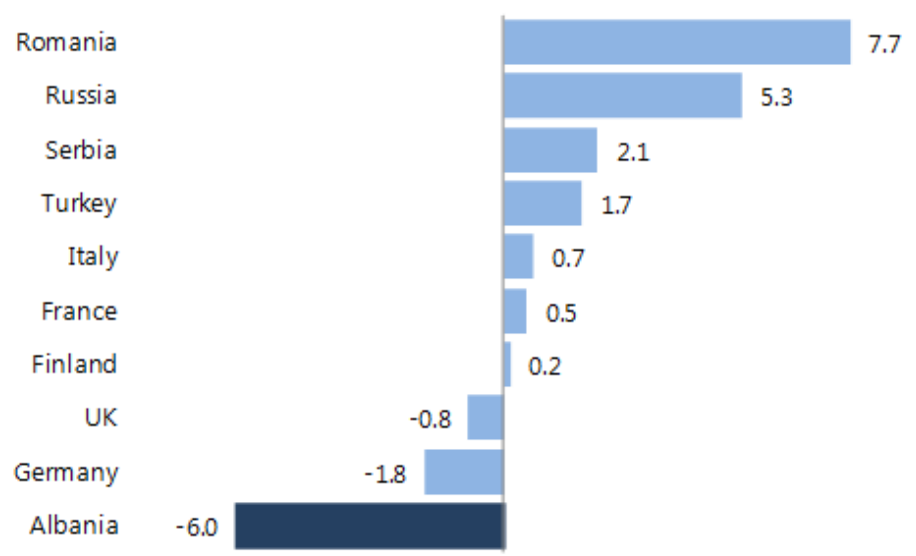

Sources: IMF staff calculations; Albania: Medium-Term Budget Program; Other countries: National budget documents. 


\subsubsection{Forecast reconciliation (Not met)}

51. The budget documentation does not explain changes between successive forecasts. In particular, there is no explanation of the differences between successive vintages of fiscal forecasts broken down into the effects of individual policy changes, new macroeconomic forecast determinants, and other factors such as classification changes. The Report on the Budget Law and the Report on the Implementation of the Budget provide some discussion and quantification of the fiscal impact of selected policy changes, but there is no explanation or quantification of the overall impact on the forecast. Similarly, the government does not publish an assessment of its past forecast accuracy, including an analysis of why outturns have differed from forecasts, as discussed in Section 2.3.1.

\section{Over the past decade there have been significant revisions between fiscal forecast} vintages, and, as set out in Section 2.1.3, relatively large errors. Figure 2.10 shows the change between successive forecasts of revenue and expenditure for a specific year and the change between the final forecast $(t)$ and outturn. In several years, there have been changes between forecast vintages of up to 15 percent of total revenues or expenditure.

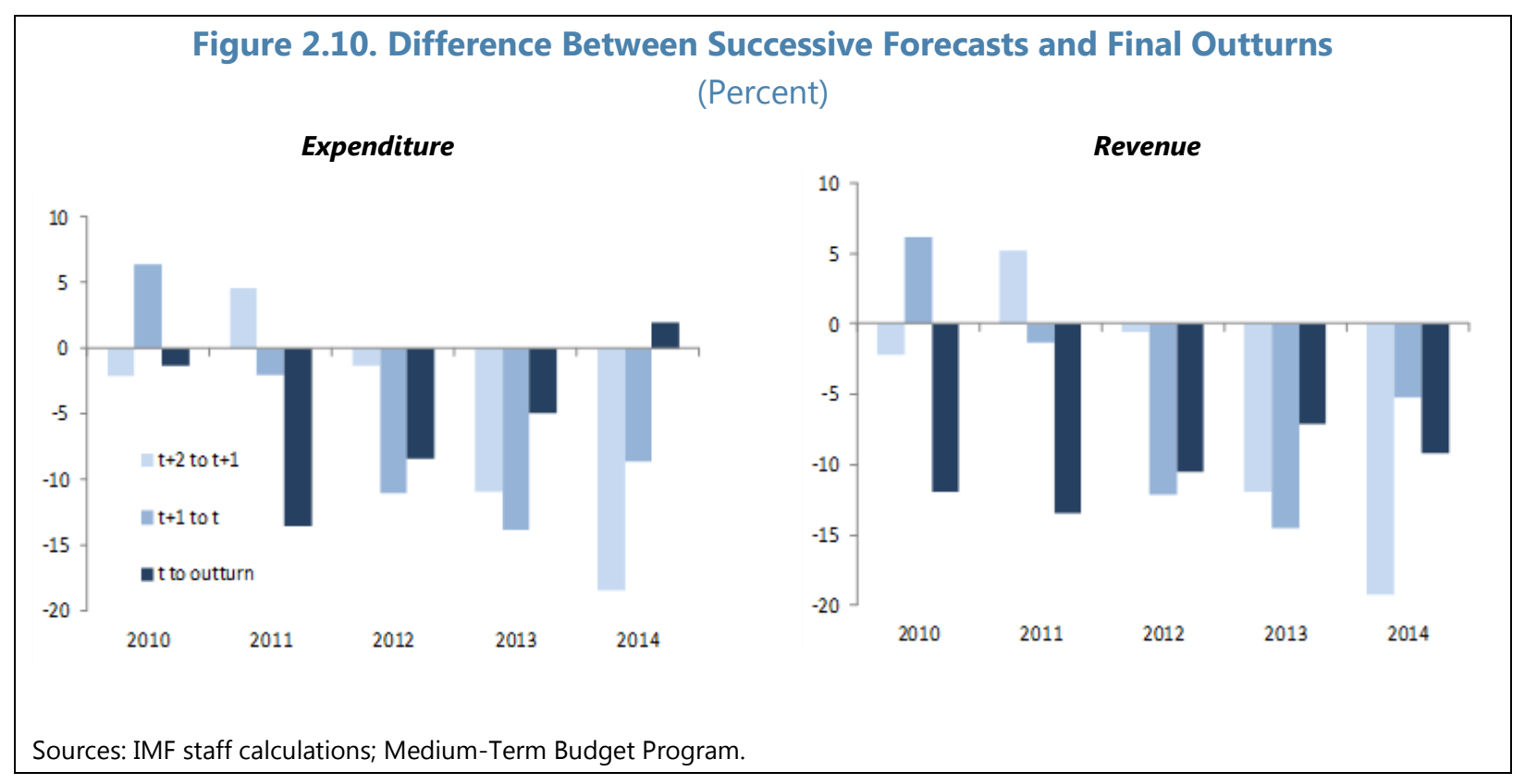

53. Publishing regular forecast reconciliations could help improve the reliability and credibility of Albania's forecasts and budget plans. Box 2.1 provides an example of how a forecast reconciliation could be used to identify the major causes of change between forecasts and outturn, and use this to improve understanding of the drivers of the fiscal position and the impact of policy decisions, and to learn lessons for subsequent forecasts and budget plans. The same type of analysis can also be used to examine changes between successive forecast vintages. 


\section{Box 2.1. Example of Forecast Reconciliation}

This box provides an example of the type of forecast reconciliation that should be published on a more detailed and systematic basis by the Ministry of Finance. Table 2.3 compares the government's 2011 medium-term forecast for revenue and expenditure with the outturn, as reported in 2015. The largest source of revenue error was VAT, which is the biggest revenue source. On expenditure there were large errors in interest spending and in capital spending (an issue highlighted in Section 2.1.4).

Table 2.3. Composition of Forecast Errors (Million lek)

\begin{tabular}{|c|c|c|c|c|c|c|c|}
\hline Revenue & 2012 & 2013 & 2014 & Expenditure & 2012 & 2013 & 2014 \\
\hline 2011 Forecast & 353,759 & 375,833 & 400,732 & 2012 Forecast & 394,922 & 419,569 & 447,366 \\
\hline 2015 Outturn & 330,384 & 327,178 & 367,949 & 2015 Outturn & 376,241 & 394,118 & 456,404 \\
\hline Difference & $-23,375$ & $-48,655$ & $-32,783$ & Difference & $-18,681$ & $-25,451$ & 9,038 \\
\hline of which: & & & & of which: & & & \\
\hline$V A T$ & $-10,766$ & $-24,458$ & $-20,571$ & Current, of which: & $-9,952$ & $-12,716$ & $-12,042$ \\
\hline Income tax & $-5,127$ & $-8,368$ & $-3,233$ & Personnel & $-1,455$ & $-2,817$ & $-3,052$ \\
\hline Excise & $-6,338$ & $-7,679$ & $-4,624$ & Interest & $-8,102$ & $-10,083$ & $-17,320$ \\
\hline Personal income tax & $-1,765$ & $-2,254$ & $-5,826$ & Operating expenses & 2,583 & 2,669 & 5,856 \\
\hline Other national taxes & 6,079 & 3,860 & 7,303 & Special funds & $-1,630$ & $-1,613$ & $-1,188$ \\
\hline Local revenues & $-3,765$ & $-6,189$ & $-7,134$ & Local budget & $-2,451$ & $-3,307$ & 62 \\
\hline Income from special funds & $-2,102$ & $-2,741$ & $-3,384$ & Other & 1,103 & 2,435 & 3,600 \\
\hline Non-tax revenue & 3,352 & 5,073 & 9,082 & Capital & $-5,829$ & $-6,149$ & $-8,586$ \\
\hline \multirow[t]{2}{*}{ Other } & $-2,943$ & $-5,899$ & $-4,396$ & Arrears repayment & 0 & 0 & 35,000 \\
\hline & & & & Other & $-2,900$ & $-6,586$ & $-5,334$ \\
\hline
\end{tabular}

Source: Medium-Term Fiscal Frameworks 2012-14 and 2016-18.

The next step would be to examine the causes of the largest errors. Figure 2.11 compares errors in the forecast of the growth of VAT to errors in the forecast of the growth of nominal private consumption, which is the main macroeconomic driver of VAT receipts. The pattern is similar, which suggests optimism in the macroeconomic forecast was an important cause of the error in the forecast of VAT receipts.

Figure 2.11. Comparison of Macro and Fiscal Forecast Errors (Percentage Points)

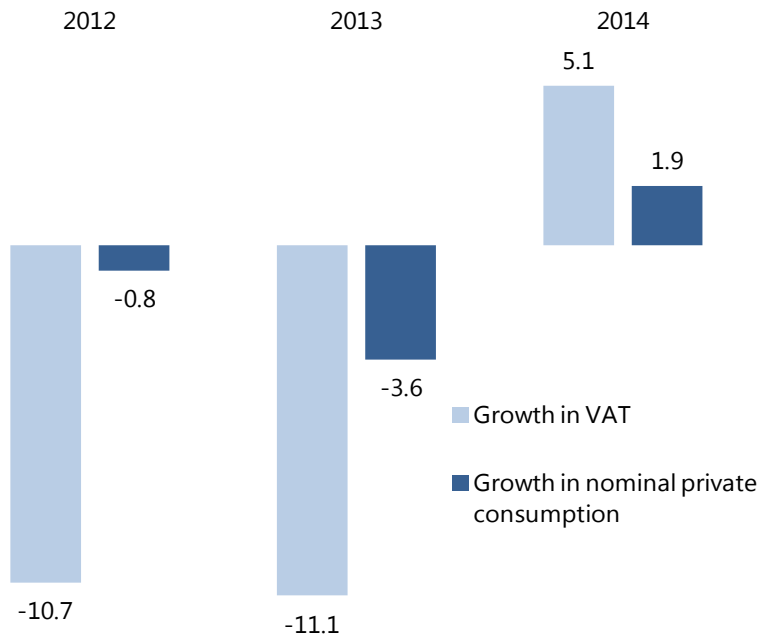

Source: IMF Staff Calculations, Economic and Fiscal Program 2012-14 and 2015-17.

Table 2.4 breaks down the forecast error for interest payments into components caused by the forecasts for the effective interest rate and the nominal debt level. The main cause of the error was the forecast of the effective interest rate. In 2011, the effective interest rate on government debt was expected to rise to 6.9 percent by 2014, but it actually fell to 4.2 percent. This was partially offset by the error on nominal debt, which was forecast to fall to 54.3 percent of GDP by 2014 , but in fact rose to 71.8 percent of GDP. 
Box 2.1. Example of Forecast Reconciliation (concluded)

A significant component of the overall error in 2013 is not explained by either nominal debt or interest rates. More detailed analysis of large errors such as this could help improve future forecasts.

Table 2.4. Decomposition of Errors in the Forecast of Interest Payments (Million lek)

\begin{tabular}{lrrr} 
Interest payments & $\mathbf{2 0 1 2}$ & $\mathbf{2 0 1 3}$ & $\mathbf{2 0 1 4}$ \\
\hline 2012 Forecast & 49,600 & 53,418 & 57,420 \\
2015 Outturn & 41,498 & 43,335 & 40,100 \\
\hline Difference & $\mathbf{- 8 , 1 0 2}$ & $\mathbf{- 1 0 , 0 8 3}$ & $\mathbf{- 1 7 , 3 2 0}$ \\
\hline Of which due to: & & & \\
$\quad$ Interest rates & $-11,361$ & $-14,552$ & $-24,054$ \\
Debt level & 4,078 & 8,157 & 7,698 \\
Other & -819 & $-3,689$ & -964
\end{tabular}

Source: IMF Staff Calculations, Economic and Fiscal Program 2012-14 and 2015-17.

Figure 2.12 provides an illustrative decomposition of errors in the government's 2011 gross debt forecast. In 2011, gross debt was forecast to fall slightly over the medium term, but in fact compared to the original debt estimate for 2011 it had increased by 16 percent of GDP by 2014. A significant driver was the higherthan-expected primary deficit over this period, partially offset by lower-than-expected interest payments. A large contribution also came from errors in the forecast of the stock-flow adjustment (i.e., the difference between the deficit and the increase in debt). This was forecast to reduce gross debt over the forecast period by 9.3 percent of GDP, but actually only caused a reduction of 1.5 percent of GDP, so causing an overall positive forecast error of 8 percent of GDP. Again, further investigation of this type of error could help improve future fiscal forecasts. It also underlines the value of debt-deficit reconciliations (Section 1.3.2)

Figure 2.12. Decomposition of Errors in the Forecast of Gross Debt (Percent GDP)

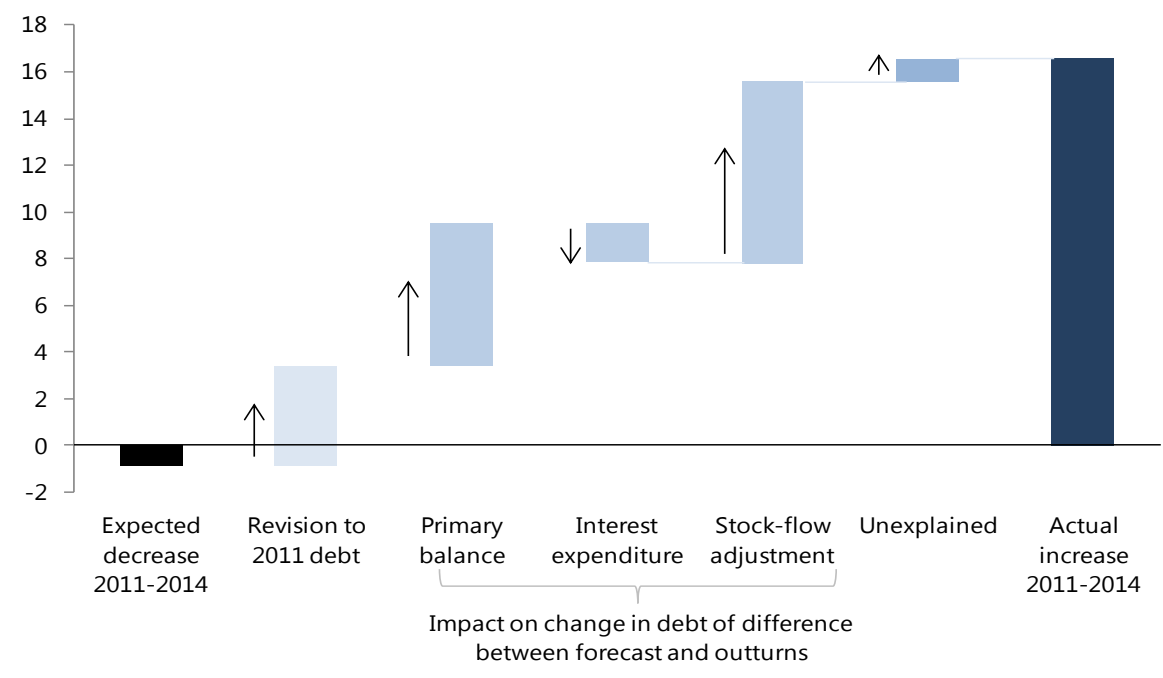




\section{E. Conclusions and Recommendations}

54. Table 2.5 summarizes the assessment of Albania's practices against the Code. It shows that in many areas Albania meets the standard of advanced or good practice, particularly in the principles related to the timeliness and orderliness of fiscal forecasting and budgeting. There is also room for improvement in several areas, particularly in the policy orientation and the credibility of annual and medium-term planning. The government's Public Finance Management Strategy 2014-20 sets out options for addressing some of these problems, such as introducing fiscal objectives and publishing a citizens' guide to the budget. It will also be important to address the optimism bias in annual and medium-term forecasts, which has led to the need to reduce expenditure compared to medium-term plans and budget allocations, in some cases without prior approval from Parliament through supplementary budgets. The management of multi-annual investment projects should also be addressed, particularly given that investment spending is relatively high as a share of GDP. The following recommendations are designed to address these issues.

55. Recommendation 2.1: Forecasts. The government should enhance the scrutiny and analysis applied to its annual and medium-term forecasts by:

- $\quad$ Requiring the budget forecast documents to include a comparison with forecasts produced by external institutions and an explanation of any significant differences;

- $\quad$ Requiring the publication in budget forecast documents of a quantification and explanation of the factors, including new policy decisions, causing changes between successive fiscal forecasts, and annually publishing a quantification and explanation of the source of forecast errors and setting out lessons for future forecasts; and

- $\quad$ Considering the case for establishing an independent fiscal council to provide an assessment of the government's forecast, if it can be given independence from political interference and provided with sufficient technical capacity without significantly reducing the pool of expertise available to the Ministry of Finance.

56. Recommendation 2.2: Public investment projects. The government should improve the transparency and management of investment projects, including public-private partnerships and projects managed by the Regional Development Fund, by:

- Publishing in budget documents the total value of its obligations for each multi-annual investment project, including: (i) expected total lifetime cost; (ii) spending appropriated in the budget year; (iii) spending prior to the budget year; and (iv) total remaining costs over the MTBP period and beyond the MTBP period;

- Consistently applying a set of general guidelines for project appraisal and cost-benefit analysis for all major investment projects and publishing the final analysis; and

- $\quad$ Ensuring all investment projects follow an open and competitive tender process. 
Table 2.5. Summary Evaluation of Fiscal Forecasting and Budgeting

\begin{tabular}{|c|c|c|c|c|}
\hline & Principle & Assessment & Importance & Rec. \\
\hline 2.1.1 & Budget Unity & $\begin{array}{l}\text { Basic: The budget is presented on a gross } \\
\text { basis but excludes several institutions which } \\
\text { should be classified to central government. }\end{array}$ & $\begin{array}{l}\text { Low: Own-source revenue is around } 3 \\
\text { percent of gross expenditures. }\end{array}$ & \\
\hline 2.1.2 & $\begin{array}{l}\text { Macroeconomic } \\
\text { Forecast }\end{array}$ & $\begin{array}{l}\text { Advanced: Budget projections are based on } \\
\text { macroeconomic forecasts with explanations } \\
\text { of key variables, their components, and the } \\
\text { underlying assumptions. }\end{array}$ & $\begin{array}{l}\text { High: Average year-ahead real GDP } \\
\text { forecast errors of } 1.5 \text { percent points over } \\
2002-13 \text {. }\end{array}$ & 2.1 \\
\hline 2.1.3 & $\begin{array}{l}\text { Medium-Term } \\
\text { Budget }\end{array}$ & $\begin{array}{l}\text { Good: Budget documentation includes } \\
\text { medium-term projections of revenues, } \\
\text { expenditures, and financing by economic } \\
\text { category, ministry, and program, but two- } \\
\text { year outturns only by economic category. }\end{array}$ & $\begin{array}{l}\text { High: Average two-year-ahead revenue } \\
\text { and expenditure errors of } 2 \text { percent } \\
\text { points of GDP over } 2002-13 \text {. }\end{array}$ & 2.1 \\
\hline 2.1.4 & $\begin{array}{l}\text { Investment } \\
\text { Projects }\end{array}$ & $\begin{array}{l}\text { Not met: The total value of obligations } \\
\text { under multi-annual investment projects is } \\
\text { not disclosed, cost-benefit analysis is not } \\
\text { published, and competitive tenders are not } \\
\text { used for all projects. }\end{array}$ & $\begin{array}{l}\text { High: Government investment averaged } \\
7 \text { percent of GDP over 2002-13, one of } \\
\text { the highest in the region. }\end{array}$ & 2.2 \\
\hline 2.2.1 & $\begin{array}{c}\text { Fiscal } \\
\text { Legislation }\end{array}$ & $\begin{array}{l}\text { Advanced: The legal framework defines the } \\
\text { timetable for budget preparation and } \\
\text { approval, key contents of budget } \\
\text { documentation, and the powers of the } \\
\text { executive and legislature. }\end{array}$ & $\begin{array}{l}\text { Low: Parliament's power to revise the } \\
\text { budget is unlimited, but revisions to the } \\
\text { submitted budget were only } 0.3 \text { percent } \\
\text { over 2002-14. }\end{array}$ & \\
\hline 2.2 .2 & $\begin{array}{l}\text { Timeliness of } \\
\text { Budget } \\
\text { Documents }\end{array}$ & $\begin{array}{l}\text { Good: The budget is submitted to the } \\
\text { legislature and published at least two } \\
\text { months before the start of the fiscal year, } \\
\text { and approved and published before the start } \\
\text { of the fiscal year. }\end{array}$ & $\begin{array}{l}\text { Low: Budgets have been routinely } \\
\text { approved by the start of the year. }\end{array}$ & \\
\hline 2.3.1 & $\begin{array}{l}\text { Fiscal Policy } \\
\text { Objectives }\end{array}$ & $\begin{array}{l}\text { Not met: The government does not } \\
\text { consistently state or report its performance } \\
\text { against measurable objectives for the public } \\
\text { finances. }\end{array}$ & $\begin{array}{l}\text { Medium: The debt ratio has been rising } \\
\text { since } 2008 \text {, reaching } 72.6 \text { percent GDP in } \\
2014 \text {. }\end{array}$ & \\
\hline 2.3.2 & $\begin{array}{l}\text { Performance } \\
\text { Information }\end{array}$ & $\begin{array}{l}\text { Advanced: Targets are set for outcomes and } \\
\text { outputs to be achieved under each policy } \\
\text { program, and progress is monitored } \\
\text { quarterly. }\end{array}$ & $\begin{array}{l}\text { Medium: Very large number of } \\
\text { performance targets, but use in the } \\
\text { budget process is limited. }\end{array}$ & \\
\hline 2.3.3 & $\begin{array}{l}\text { Public } \\
\text { Participation }\end{array}$ & $\begin{array}{l}\text { Not met: There is no accessible citizens' } \\
\text { guide to the budget and public participation } \\
\text { in the budget is limited. }\end{array}$ & $\begin{array}{l}\text { Medium: Open Budget Survey finds } \\
\text { opportunities for public participation in } \\
\text { budgeting are limited. }\end{array}$ & \\
\hline 2.4.1 & $\begin{array}{l}\text { Independent } \\
\text { Evaluation }\end{array}$ & $\begin{array}{l}\text { Not met: Forecasts are not compared to } \\
\text { those of external institutions or subject to } \\
\text { independent evaluation. }\end{array}$ & $\begin{array}{l}\text { High: Macroeconomic and fiscal } \\
\text { forecasts have been unrealizable, as set } \\
\text { out in Sections 2.1.2 and 2.1.3. }\end{array}$ & 2.1 \\
\hline 2.4 .2 & $\begin{array}{l}\text { Supplementary } \\
\text { Budget }\end{array}$ & $\begin{array}{l}\text { Basic: The budgetary system law sets out } \\
\text { procedures governing in-year changes to the } \\
\text { budget, but material changes are made } \\
\text { without prior approval by Parliament. }\end{array}$ & $\begin{array}{l}\text { High: Approved spending was reduced } \\
\text { by } 6 \text { percent on average over 2002-14. }\end{array}$ & 2.1 \\
\hline 2.4.3 & $\begin{array}{c}\text { Forecast } \\
\text { Reconciliation }\end{array}$ & $\begin{array}{l}\text { Not met: Budget documentation does not } \\
\text { explain changes from previous fiscal } \\
\text { forecasts. }\end{array}$ & $\begin{array}{l}\text { High: Changes between forecast } \\
\text { vintages have reached } 15 \text { percent of } \\
\text { revenues and expenditures. }\end{array}$ & 2.1 \\
\hline
\end{tabular}




\section{FISCAL RISKS}

57. This section assesses the government's analysis, reporting, and management of fiscal risks compared to the practices set out in the Code. It looks at three dimensions of the issue:

- General arrangements for disclosure and analysis of fiscal risks;

- $\quad$ Reporting and management of risks emanating from specific sources, such as government guarantees, public partnerships, and the financial sector; and

- Coordination of fiscal decision-making between central government, local government, and public corporations.

58. The analysis reveals that Albania performs well against the Code in several areas. The government discloses several sources of risk and analyzes the sensitivity of revenue and the deficit to economic growth (the main reports discussing fiscal risks are listed in Table 3.1). The budget includes a contingency line and a reserve fund to cope with revenue shortfalls and emergencies. Government borrowing is authorized by law, and risks surrounding debt are analyzed and reported. Government guarantees are disclosed, controlled by law, and counted in the main measure of debt. Local governments' spending and revenue are reported monthly, and their borrowing is controlled by law. The Department of Civil Emergencies monitors and analyzes environmental risks. Financialsector risks are discussed in several reports, including those of the Bank of Albania.

\section{But there are three areas where the standard of basic practice in the Code is not met.}

There is no assessment of the long-term sustainability of public finances, no disclosure of the lifetime fiscal costs of the public-private partnerships, and insufficient reporting of natural resources. In some other areas, the standard of basic practice is met, but the government's exposure to risks is high. For example, the budget shows transfers to public corporations and the accounts of each major corporation are publicly available, but the government does not publish a report on the liabilities or financial performance of the sector, even though it has often had to subsidize many of the companies, including those in the electricity and water-supply sectors. 


\begin{tabular}{|l|c|c|}
\hline \multicolumn{1}{|c|}{ Title } & \multicolumn{1}{|c|}{ Fiscal Risks Discussed } \\
\hline $\begin{array}{l}\text { National Economic Reform } \\
\text { Program 2015-2017 }\end{array}$ & $\begin{array}{c}\text { Macroeconomic risks, including sensitivity } \\
\text { analysis, specific fiscal risks, financial-sector } \\
\text { risks }\end{array}$ & $\begin{array}{c}\text { Ministry of Finance and Ministry of } \\
\text { Economy }\end{array}$ \\
\hline $\begin{array}{l}\text { Budget Report } \\
\text { Pension Policy Paper, 2014 }\end{array}$ & $\begin{array}{c}\text { Specific fiscal risks, including contingencies } \\
\text { Long-term risks of pension scheme }\end{array}$ & $\begin{array}{c}\text { Ministry of Finance and Ministry of } \\
\text { Economy }\end{array}$ \\
\hline $\begin{array}{l}\text { Medium Term Debt Strategy, } \\
\text { 2015-2017 }\end{array}$ & $\begin{array}{c}\text { Debt risks related to refinancing, interest } \\
\text { rates, exchange rates, and operations. }\end{array}$ & $\begin{array}{c}\text { Public-Debt Department, Ministry of } \\
\text { Finance }\end{array}$ \\
\hline $\begin{array}{l}\text { Debt Indicators } \\
\text { Dinancial Stability Report }\end{array}$ & Financial-sector risks & $\begin{array}{c}\text { Public-Debt Department, Ministry of } \\
\text { Finance }\end{array}$ \\
\hline $\begin{array}{l}\text { Annual Report } \\
\text { Source: All documents can be found on the websites of the respective agencies. }\end{array}$ & Bank of Albania \\
\hline
\end{tabular}

\section{A. Disclosure and Analysis}

\subsubsection{Macroeconomic risks (Basic)}

60. Macroeconomic risks are analyzed in the National Economic Reform Program. This is an annual document prepared and published by EU candidate countries that discusses policy and planned reforms. The document shows alternative paths for growth and their implications for government revenue and the deficit. However, this analysis remains a formal exercise: no sensitivity analysis is included in the Macroeconomic and Fiscal Framework, which is the main document used to prepare the annual budget and the medium-term budget program.

\section{Although macroeconomic risks are large, Albania's economy has been more stable in} recent years than those of many other countries. Figure 3.1 shows the relationship between the volatility of GDP and the volatility of revenue, measured as the standard deviation of real growth since 2001. Among other things, it shows that neither GDP nor revenue has been unusually volatile. This suggests that the large forecast errors of the past decade have been due to weaknesses in the forecast process, rather than to the volatility of the economy (see Section II). 
Figure 3.1. Volatility of Real GDP and Government Revenue, European Countries (Standard deviation of growth rates in percent)

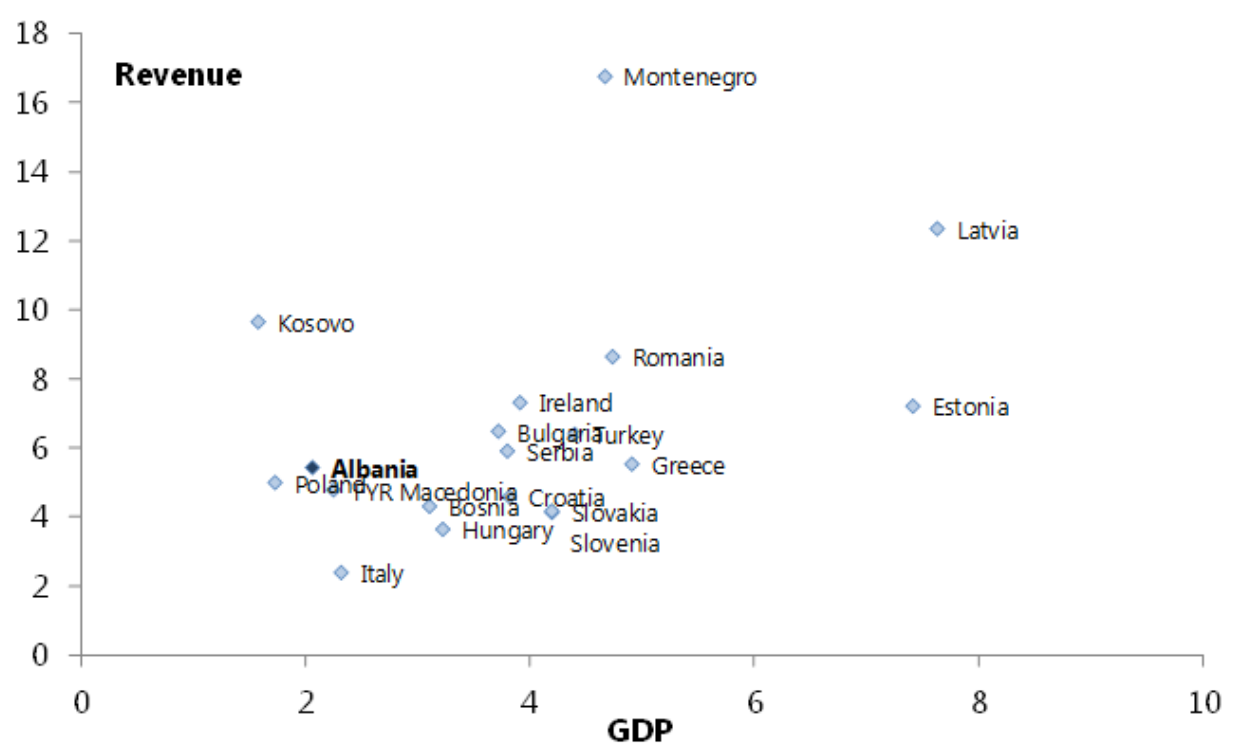

Source: IMF, World Economic Outlook database, April 2015

Note: Revenue is deflated at the consumer price index. Volatility is measured as the standard deviation of changes in the period 2001-14.

\subsubsection{Specific fiscal risks (Basic)}

62. Many specific fiscal risks are discussed and quantified in budget documents. The 2015 budget report, which had more information on risks than previous editions, disclosed such risks as possible revenue shortfalls, guarantees for the electricity sector that might have to be issued in the fiscal year, and property compensation expected to be awarded by the International Court of Human Rights. The National Economic Reform Programme 2015-17 discussed but did not quantify the risk from unfinanced commitments in investment projects that exceed medium-term budget ceilings (of about 1.8 percent of GDP according to the Ministry of Finance). Other risks such as those related to guaranteed bank deposits are described in other reports, but are not included in any summary report on risks.

63. Other significant risks are not quantified or discussed in budget documents. The unguaranteed loans and other liabilities of the electricity sector are sizeable (1.9 percent of GDP) but not included in any report on risk. Nor has the government estimated the bill (paid in small installments over many years) for compensating people whose property was expropriated during the communist era. Rough estimates made by various sources, including the World Bank, put the bill in range of several billion euros. ${ }^{11}$ The remaining bill for compensating victims of political persecution in the communist era (2.8 percent of GDP), also paid in installments, is similarly undisclosed. Table 3.2 lists these and other specific fiscal risks, discussed below, to which the

\footnotetext{
${ }^{11}$ World Bank, Governance in the Protection of Immovable Property Rights in Albania: A Continuing Challenge, April
} 2012, p. 11. 
government is exposed. It shows the government's gross exposure (the most the government could be required to spend in a worst-case scenario) and does not indicate likely expenditure. It excludes guarantees already counted in the public debt.

Table 3.2. Size of Selected Specific Fiscal Risks Not Quantified in Budget, Recent Estimates

\begin{tabular}{lr}
\hline Risk & Size \\
\hline Unfunded commitments in investment projects & Percent of GDP \\
Compensation for expropriated property & 2 \\
Compensation for political persecution & 30 \\
Liabilities of public corporations except central bank not included in debt & 8 \\
Public-private partnerships & 7 \\
Liabilities of banks & 96 \\
\hline
\end{tabular}

Sources: Ministry of Energy and Industry, Ministry of Finance; World Bank; Bank of Albania; IMF staff calculations.

\subsubsection{Long-term sustainability of public finances (Not met)}

64. No long-term fiscal projections are published. The only report of this kind has been a one-off report on pensions, which did not project the government's total debt or deficit. ${ }^{12}$

65. Long-term risks are, however, important. Although Albania has a younger population than that of many other European countries, its population is declining because of emigration and a falling birth rate, so the ratio of working-age to older people is falling. The government changed the pension scheme in 2014 to gradually close the gap in retirement ages for men and women and to reduce the extent to which the scheme redistributed income. The scheme is projected to be selfsustaining only in 2042 and to return to deficit later (Figure 3.2). There is also the cost of supplementary pension schemes for the military, police, and senior officials, which although small, is growing and is paid mostly from the budget (see Section 1.1.2).

\footnotetext{
${ }^{12}$ Ministry of Social Welfare and Youth, The Pension Policy Paper, April 2014.
} 
Figure 3.2. Albania: Projection of Pension Scheme's Balance, 2014-78

(Percent of GDP)

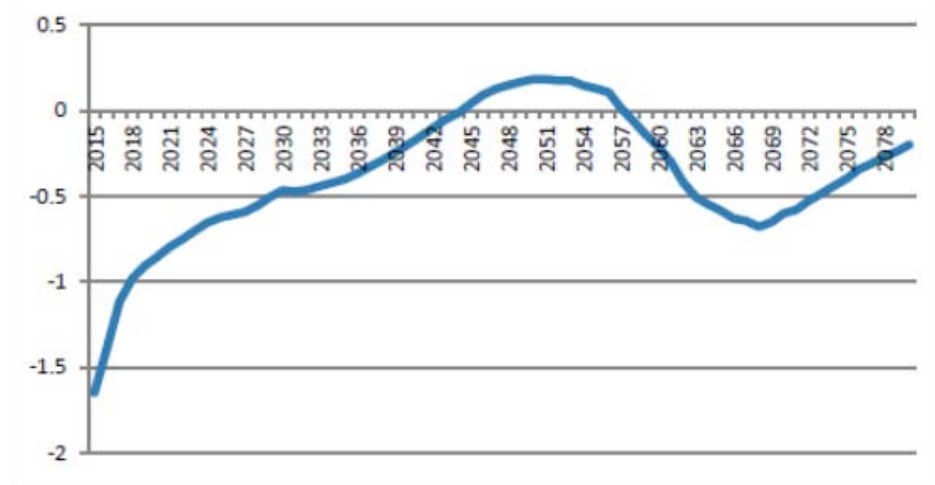

Source: Ministry of Social Welfare and Youth, Pension Policy Paper, 2014.

\section{B. Risk Management}

\subsubsection{Budgetary contingencies (Basic)}

66. The budget includes a contingency line and a reserve fund, but they are small and the criteria for their use are not specified. The purpose of the contingency line $(0.8$ percent of expenditure in 2015) is to deal with shortfalls in revenue, whereas the reserve fund ( 0.3 percent of expenditure) is used at the discretion of the Council of Ministers, usually to cope with emergencies or other unexpected expenditure needs. By law, the two can sum to 3 percent of total expenditure. While their possible uses are spelled out in the annual budget law, the circumstances in which they can be spent are not precisely specified. Nor are there regular in-year reports on their utilization, though the Supreme State Audit reports their use in its annual audit report on the state budget. In practice, the contingency line has been too small to cover the large shortfalls in revenue caused by biased forecasts (Section 2). It has also been used to permanently increase wages and pensions. Conservative estimates of interest spending may have served as a de facto contingency line.

\subsubsection{Assets and liabilities (Basic)}

67. Government borrowing is authorized by law, and risks surrounding government debt are reported regularly. The Medium-Term Macroeconomic Framework and the annual budget law set ceilings on new borrowing and the guarantees that can be issued. The medium-term debt strategy discusses rollover, interest-rate, exchange-rate, and operational risks for public debt, as well as strategies to manage risks. The National Economic Reform Program reports the sensitivity of debt to the exchange rate, interest rates, and growth. Quarterly debt reports provide detailed information on debt and guarantees. The Arrears Clearance and Prevention Strategy, adopted in 2014, discussed the treatment of arrears accumulated until the end of 2013 (estimated at 5.2 percent of GDP) as well 
as measures to prevent the reoccurrence of arrears. A quarterly survey of new arrears is now published by the Ministry of Finance. ${ }^{13}$

\section{The risks surrounding debt, at $\mathbf{7 2 . 6}$ percent of GDP including arrears, are high.} Domestic debt (40 percent of GDP) has an average maturity of less than two years, and domestic refinancing needs in 2014 were 24 percent of GDP. A large share of the domestic debt is held by foreign-owned banks, which makes the government vulnerable to the risk that they will reduce their exposure to Albania, for example to comply with the regulations of their supervisors in their home countries. To mitigate refinancing risks associated with domestic debt, the government intends to replace part of it with longer term external debt. External debt has lower interest rates, but exposes the government to exchange-rate risk. In 2014, the depreciation of the lek increased the stock of debt by 0.9 percent of GDP.

69. Information on assets is scarce. As shown in Table 1.3, financial assets are estimated at 17.8 percent of GDP in 2013. The government does not have a published strategy for managing its investments in public corporations and the dividends it receives are very small (0.08 percent of GDP on average in the past decade). Information on nonfinancial assets exists, but is not comprehensive, audited, or published (Section 1).

\subsubsection{Guarantees (Good)}

70. Guarantees are reported, controlled by law, and counted in public debt. The ceiling on new guarantees that can be issued in the budget year is set in the budget law (Article 18 in the 2015 law). Information about guarantees, their beneficiaries, and the government's gross exposure is published quarterly in the Summary of the Debt Register by the Ministry of Finance. However, published reports do not discuss the probability of guarantees' being called or report on cases in which the Ministry of Finance has had to service a guarantee. All guarantees are, however, included in the stock of the public debt, and when forecasting debt-service costs, the Ministry of Finance takes a conservative approach, assuming it will have to service all electricity-sector guarantees and a large share of the others.

\section{Government guarantees have grown in recent years, but were only 3.9 percent of GDP}

in 2014. The overwhelming majority of the guarantees ( 85 percent) have been given to electricity companies and are likely to be called. Other guarantees have been issued to the water sector, infrastructure, and agriculture (Figure 3.3). Although the level of guarantees is lower than in many advanced economies, it is higher than in most other countries in Central and Eastern Europe (Figure 3.4). There are no guarantees given by local governments to water companies.

\footnotetext{
${ }^{13}$ Ministry of Finance, Information on New Arrears Created October-December 2014.
} 
Figure 3.3. General Government Guarantees by Sector, March 2015

(Millions of lek)

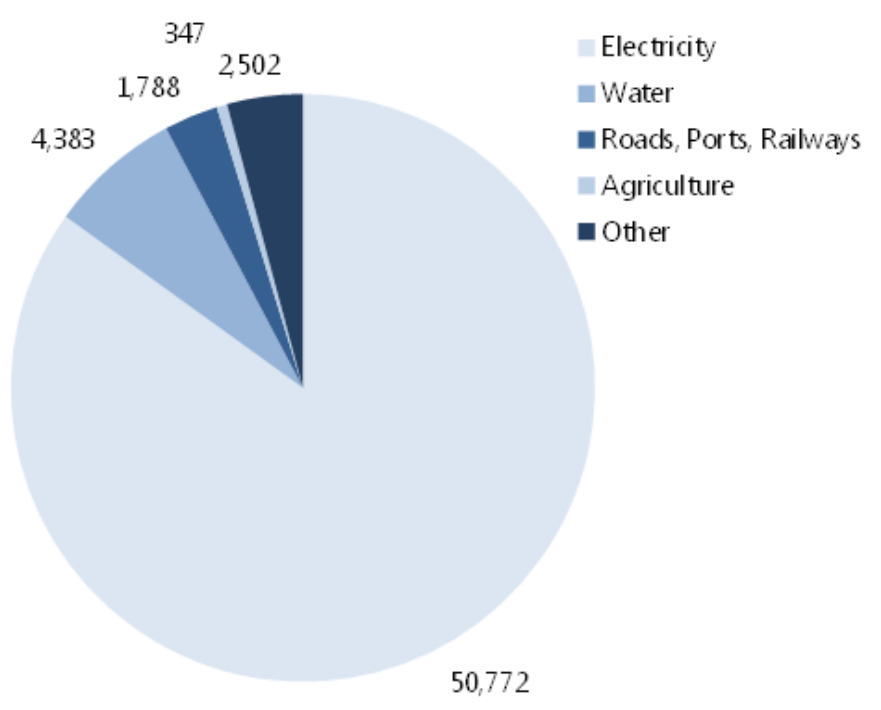

Source: Ministry of Finance, Debt Indicators, first quarter, 2015.

Figure 3.4. General Government Guarantees, Europe, 2014

(Percent of GDP)

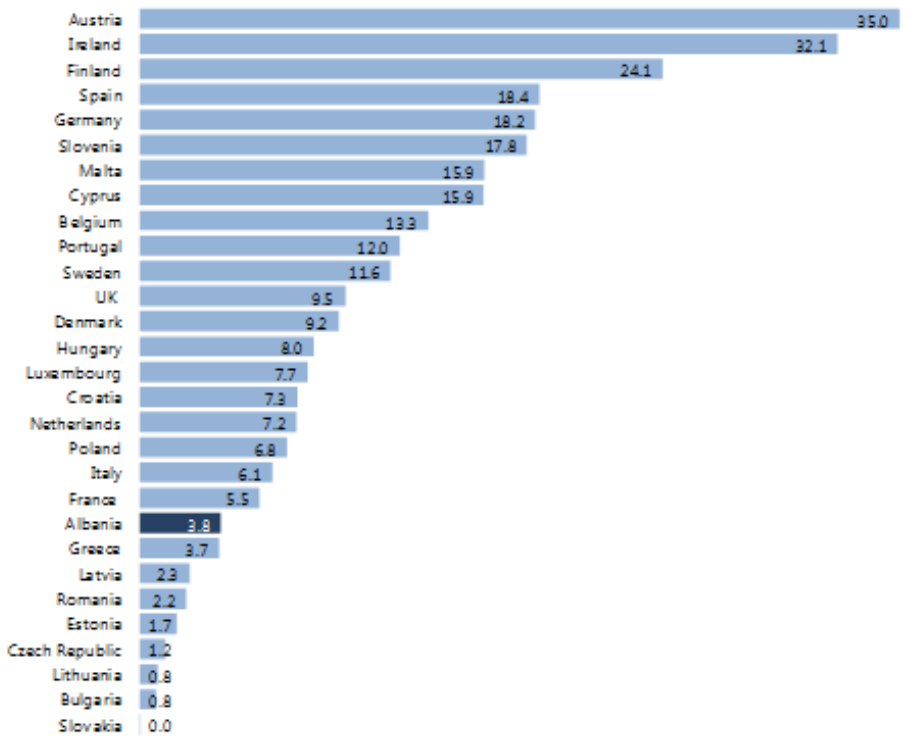

Source: Eurostat, Ministry of Finance.

\subsubsection{Public-private partnerships (Not met)}

72. The government does not report on its obligations in public-private partnerships. The law requires the Ministry of Finance to keep a register of public-private partnerships and to assess their budgetary impact before they are signed, but the government does not publish a register and does not disclose projections of its expected or possible payments over the lives of the contracts. As 
noted in Section 1.1.2, it also does not recognize the investment in the projects as debt-financed government spending.

73. At least 55 public-private partnerships have been signed, ${ }^{14}$ creating commitments with a present value of about 7 percent of GDP. The government's electricity-generation company, $\mathrm{KESH}$, has entered into contracts with hydropower producers (with payments worth 4 percent of GDP). Tirana airport is operated under a 30-year concession that began in 2005, in which the concessionaire benefits from a 9 million euro guarantee and a monopoly over the landing and departure of international flights. There are also contracts for a scanning service (2 percent of GDP), a national health-checkup service (1 percent of GDP), and a waste-management project at Elbasan. Many new projects are being undertaken or planned, including for the Milot-Morinë and Arbëri roads, the last project having an estimated cost of 2 percent of GDP.

\subsubsection{Financial sector (Advanced)}

74. Deposit insurance is disclosed and an assessment of financial-sector stability is undertaken regularly. The Deposit Insurance Agency reports annually the amount of insured deposits as well as information on its insurance fund. The Bank of Albania publishes twice a year the Financial Stability Report, which assesses financial-sector risks and reports on various stress tests. The Financial Stability Advisory Group, which monitors financial-sector risks and coordinates actions between different actors, assesses but does not publish estimates of the possible fiscal costs of a financial crisis.

\section{Albania's banking system is larger than those of most emerging European countries.}

Its assets were 95 percent of GDP at the end of 2013, whereas the average for emerging European countries was only 65 percent. Analysis by the Bank of Albania and the IMF shows that risks remain high. ${ }^{15}$ Nonperforming loans were 23 percent of total loans at the end of 2014 (Figure 3.5), among the highest in central and eastern Europe, though the loans are provisioned and banks are well capitalized. The capital-adequacy ratio at the end of 2014 was 16.8 percent, well above the regulatory minimum of $12 .{ }^{16}$ Proximity to Greece raises also concerns of contagion, although the Greek-owned banks in Albania operate as subsidiaries. Table 3.3 shows that total deposits of the banking system are 73 percent of GDP, most of which are insured. Deposits of individuals (but not firms) up to 2.5 million lek per bank are insured. ${ }^{17}$ The Deposit Insurance Agency had a fund of 24 billion lek (1.7 percent of GDP) at the end of 2014 and has signed a credit line with the European Bank of Reconstruction and Development for 100 million euro, guaranteed by the government. By law, the government is responsible for the scheme's obligations.

\footnotetext{
${ }^{14}$ See Open Data Albania, a project of the Albanian Institute of Science.

${ }^{15}$ IMF Staff Report, March 2015, pp. 12-13, 17; Bank of Albania, Financial Stability Report, 2, 2014, p. 17.

${ }^{16}$ Bank of Albania, Financial Stability Report, 2, 2014, p. 65, Table 8.4. From 2016, loans-and-saving associations will be included in the scheme for deposits up to 2 million lek.

${ }^{17}$ Law number 53 of 2014,"On deposit insurance."
} 
Figure 3.5. Nonperforming Loans in Selected European Countries, 2014

(Percent of total)

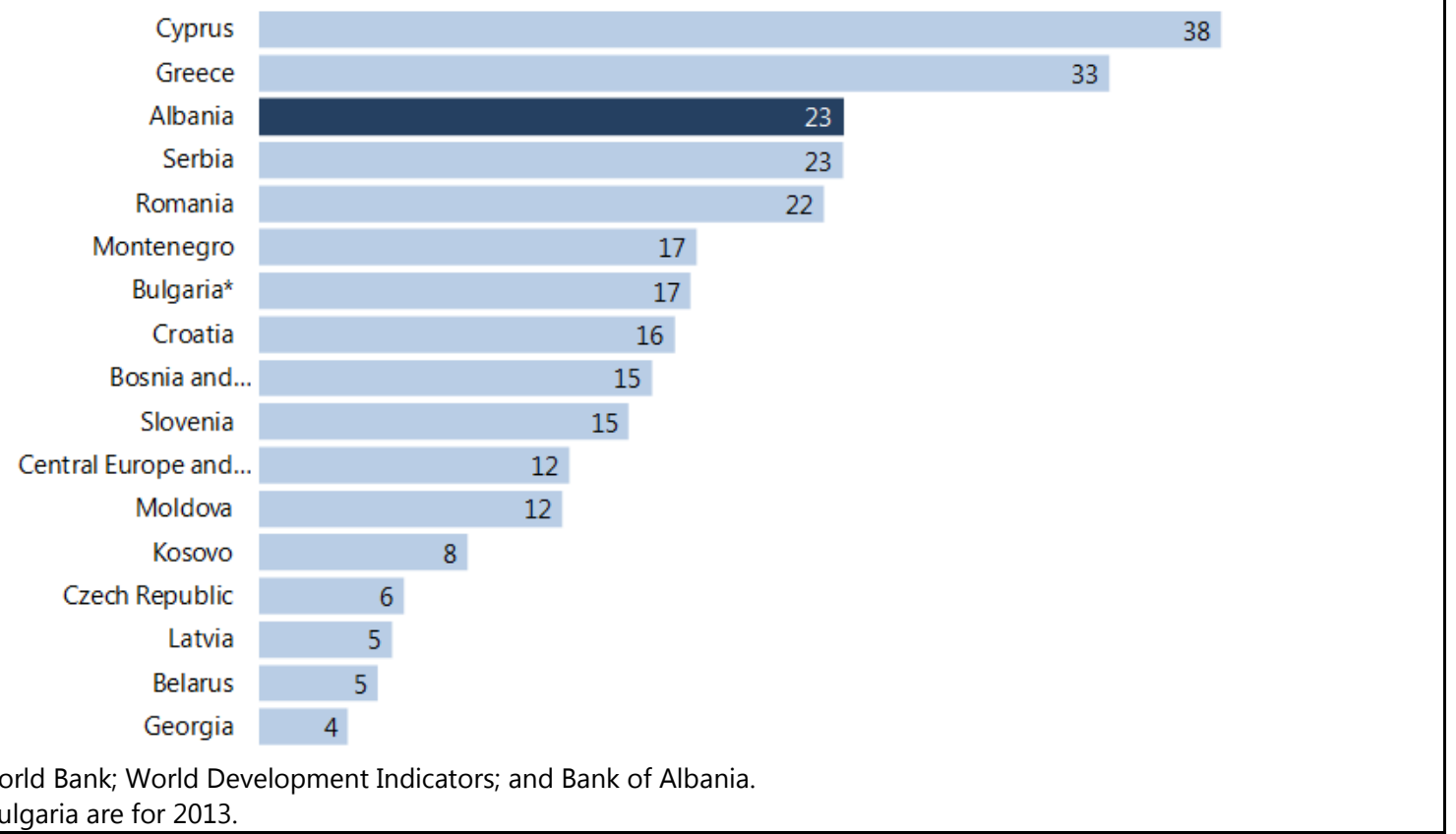

Data for Bulgaria are for 2013.

Table 3.3. Albania: Bank Liabilities, 2013

\begin{tabular}{lr}
\hline Liability & $\begin{array}{r}\text { Amount } \\
\text { (Percent of GDP) }\end{array}$ \\
\hline Total & 95 \\
of which deposits & 73 \\
of which insured & 62 \\
\hline
\end{tabular}

Source: Bank of Albania and Deposit Insurance Agency.

\subsubsection{Natural Resources (Not met)}

76. The budget shows receipts from royalties, but the government does not publish annual estimates of the volume and value of major natural resources. Some data on the annual volume of oil, coal, and other energy products, as well as timber production, are published by the Institute of Statistics.

77. Albania is rich in natural resources, but revenue from royalties is small. Proven reserves of oil are the 63th largest in the world, and the country also has gas and mineral deposits, including chromium. Concessions for the exploitation of mineral resources are awarded by the National Agency of Natural Resources. In 2014, royalties, mostly from oil, were 6.5 billion lek, or about 2 percent of total revenues. 


\subsubsection{Environmental risks (Basic)}

78. Environmental risks are discussed, but not quantified in budget reports. The 2015 budget report also took into account the importance of rainfall for the subsidies or guarantees the government would need to give to electricity sector, which are reliant on hydro-electricity.

79. Albania is vulnerable to floods, earthquakes, and other environmental risks, but at least recently the costs have been low. According to the Civil Protection Agency, Albania is one of the countries with the highest economic risk in the world from multiple hazards, with 86 percent of its territory prone to two or more disasters. Earthquakes are a high hazard according to the European Seismic Hazard Map, though the last earthquake that caused serious damage was in 1979. The most frequent disasters are major floods, which are especially common in the North East and South East of the country. The government pays some of the costs caused by floods, but the annual costs were only 0.02 percent of GDP on average in the past five years. Other risks include forest fires, droughts, and industrial accidents. Damages paid following the explosion of ammunition demolition factory in Gërdec in 2008 amounted to 2.5 billion lek over two years ( 0.2 percent of GDP).

\section{Coordination}

\subsubsection{Subnational governments (Good)}

80. Reporting on the revenue and spending of local governments is extensive, and their debt is constrained by law. ${ }^{18}$ Data on revenue and spending are published monthly on a consolidated basis and quarterly on a unit level, including spending by function, in the Ministry of Finance's quarterly fiscal statistics. Data on the assets and non-debt liabilities of local governments-including their arrears-are not published, though the government plans to undertake an inventory of these, as well as their contractual commitments. Government's ability to understand the fiscal position of the local government sector is therefore limited. The Ministry of Finance has a veto on any borrowing by local governments.

81. Local governments' spending is low, as is their debt. They have responsibilities for preuniversity education, local infrastructure, water provision, sewage and waste management, and other services. Their spending is about 8 percent of the spending of general government (2.4 percent of GDP), which is low compared to other European countries (Figure 3.6). As noted in Section 1.1.1, a recent reform will reduce the number significantly, eliminating the mostly inefficient and financially dependent communes. At the end of March 2015, only six local governments had outstanding loans, and their total debt was less than 0.1 percent of GDP. Many more, however, could have arrears.

\footnotetext{
${ }^{18}$ Law number 9,869 of 2008, "On Local Government Borrowing."
} 
Figure 3.6. Spending of Local Government in European Countries, 2014

(Percent of GDP)

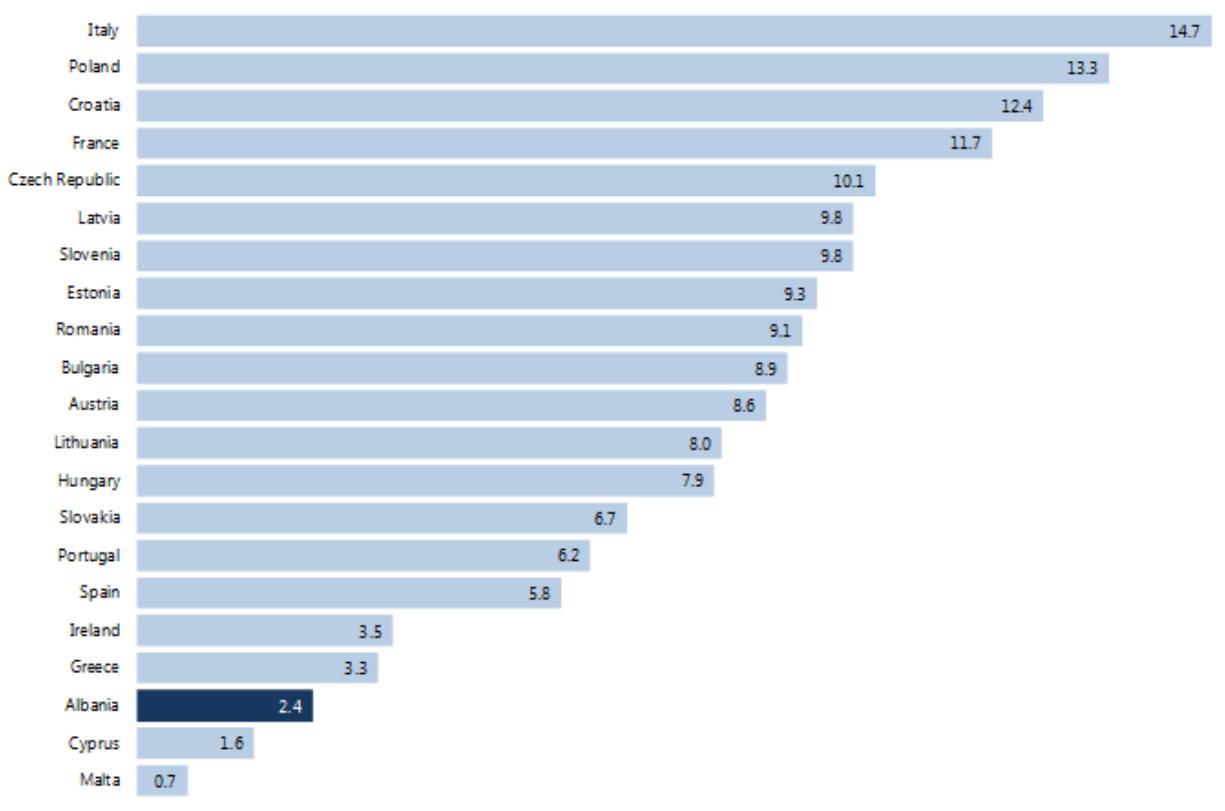

Sources: Eurostat; Ministry of Finance.

\subsubsection{Public corporations (Basic)}

82. There is no report on the finances of the public-corporations sector. The financial statements of individual public corporations, like other joint-stock companies, are generally published by the National Registration Centre. Ownership of 255 public corporations is distributed among various ministries and local government. The Ministry of Economy is in charge of administering public property, but it does not prepare consolidated financial statements for the government's portfolio of companies or report quasi-fiscal activities. Transfers between the government and public corporations are published in the budget.

83. Public corporations create significant fiscal risks. As Figure 3.7 shows, the largest 12 (by revenue) had aggregate liabilities of about 20 percent of GDP at the end of 2013. (Some of these liabilities are owed to other public corporations.) Although the sector is smaller than those of many advanced European countries (Figure 3.8), the governance and financial performance of the companies is weak. They operate under commercial law, but several, especially in the electricity and water-supply sectors, run losses, receiving direct or indirect support from the budget. The electricity sector is in deep trouble after the failed privatization and later reacquisition of the distribution company, OSHEE. The sector is expected to need budget support until 2019. The water-supply companies, which are owned by local governments, covered only 85 percent of their costs with their own revenue in 2014. They rely frequently on budget transfers, mostly to cover their electricity bills. The railway company also receives modest subsidies. 
Figure 3.7. Unconsolidated Liabilities of Largest Public Corporations, 2013

(Percent of GDP)

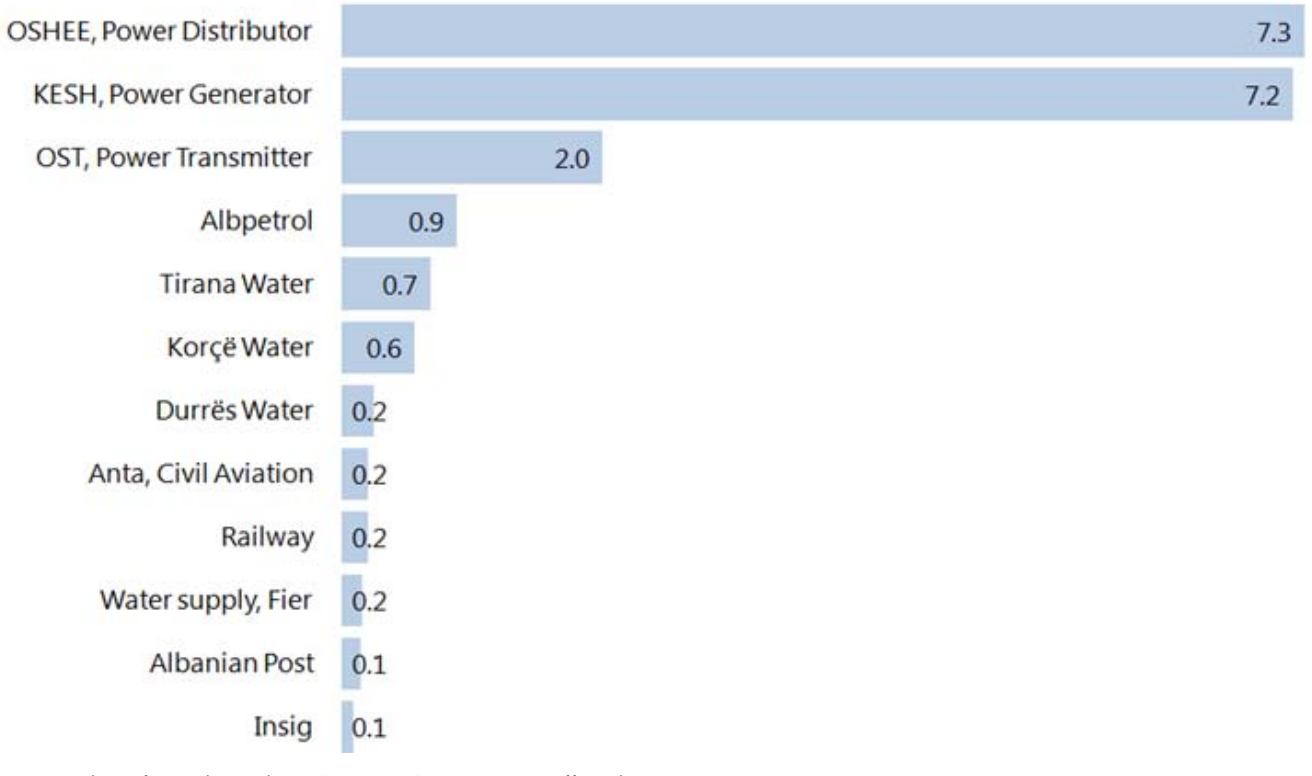

Sources: National Registration Centre. Open Data Albania.

Figure 3.8. Liabilities of Public Corporations, European Countries, 2013

(Percent of GDP)

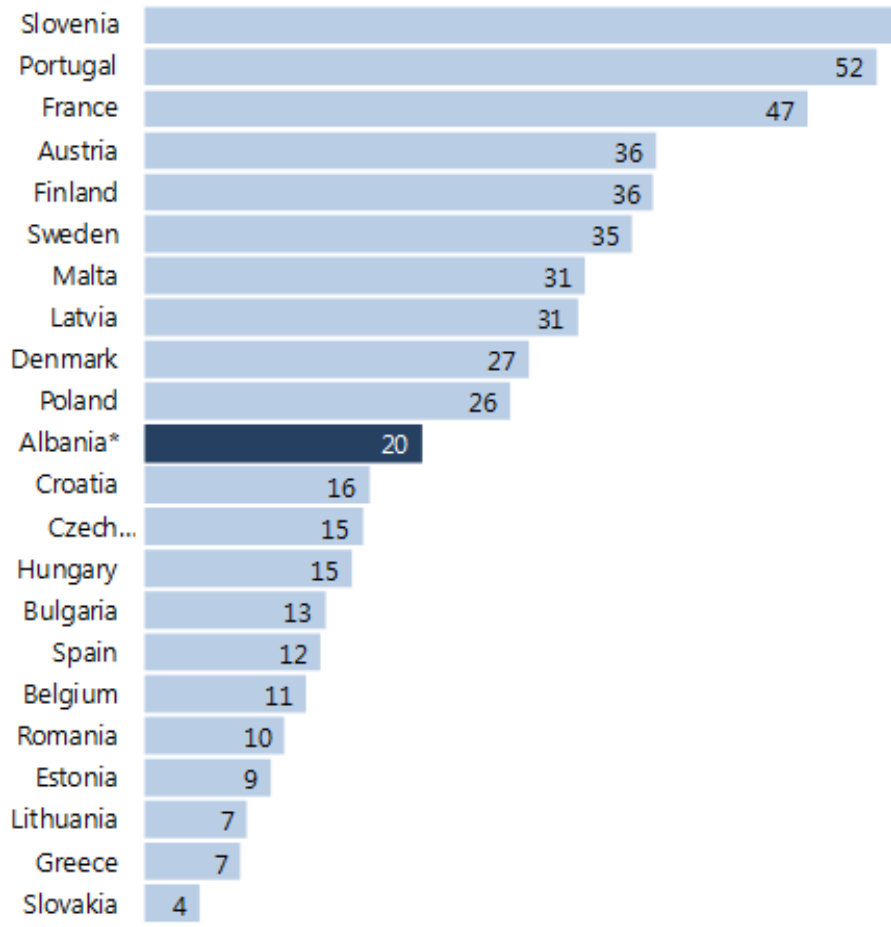

Sources: Eurostat and Figure 3.7. Note: * Twelve largest corporations. 


\section{Conclusions and Recommendations}

84. Table 3.4 summarizes the assessment of Albania's practices against those of the Code. It shows that Albania meets at least the standard of basic practice in 9 of the Code's 12 dimensions. The government could improve reporting on risks related to several issues, including long term sustainability and public-private partnerships.

85. Recommendation 3.1. Reporting on fiscal risks. The report on fiscal risks included in budget documentation should progressively be increased in scope and depth. It should estimate the sensitivity of the government's revenue, deficit, and debt to economic growth and other important macroeconomic variables. It should also describe and where possible quantify a larger range of specific fiscal risks including:

- $\quad$ Explicit and implicit guarantees of the liabilities of public corporations;

- The government's rights and obligations in public-private partnerships;

- Unfunded commitments related to public investment projects;

- The possible cost of compensation programs; and

- $\quad$ Long-term risks created by pensions, healthcare, and other spending programs.

86. Recommendation 3.2. Oversight of public corporations. The authorities should put in place appropriate measures to ensure comprehensive oversight of all public corporations. 
Table 3.4. Summary Evaluation: Fiscal Risks

\begin{tabular}{|c|c|c|c|c|}
\hline & Principle & Assessment & Importance & $\operatorname{Rec}$ \\
\hline 3.1.1 & $\begin{array}{l}\text { Macroeconomic } \\
\text { Risks }\end{array}$ & $\begin{array}{l}\text { Basic: Some sensitivity analysis is } \\
\text { presented in the National Economic } \\
\text { Reform Program 2015-2017. }\end{array}$ & $\begin{array}{l}\text { Medium: The volatility of GDP was } \\
2.1 \text { percent in 2001-14. }\end{array}$ & 3.1 \\
\hline 3.1.2 & $\begin{array}{l}\text { Specific Fiscal } \\
\text { Risks }\end{array}$ & $\begin{array}{l}\text { Basic: The } 2015 \text { budget report } \\
\text { discussed and quantified some fiscal } \\
\text { risks, but not all the major ones. }\end{array}$ & $\begin{array}{l}\text { High: Exposure from unquantified risks } \\
\text { exceeds } 76 \text { percent of GDP. }\end{array}$ & 3.1 \\
\hline 3.1.3 & $\begin{array}{l}\text { Long-Term Fiscal } \\
\text { Sustainability }\end{array}$ & $\begin{array}{l}\text { Not Met: The government does not } \\
\text { produce long-term projections of the } \\
\text { deficit or debt. }\end{array}$ & $\begin{array}{l}\text { Medium: Pension costs are large, but } \\
\text { a recent reform is expected to } \\
\text { gradually reduce the pension deficit. }\end{array}$ & 3.1 \\
\hline 3.2 .1 & $\begin{array}{l}\text { Budgetary } \\
\text { Contingencies }\end{array}$ & $\begin{array}{l}\text { Basic: The budget includes } \\
\text { contingencies and a reserve fund, but } \\
\text { criteria for their use are not spelled } \\
\text { out in the budget law. }\end{array}$ & $\begin{array}{l}\text { Medium: Contingency and reserves } \\
\text { were } 1.1 \text { percent of spending in } 2015 \text {, } \\
\text { too small to cushion risks. }\end{array}$ & \\
\hline 3.2 .2 & $\begin{array}{l}\text { Asset-and-Liability } \\
\text { Management }\end{array}$ & $\begin{array}{l}\text { Basic: Government borrowing is } \\
\text { authorized by law and risks } \\
\text { surrounding debt (but not assets) are } \\
\text { regularly reported. }\end{array}$ & $\begin{array}{l}\text { High: Debt is high at } 72.6 \text { percent of } \\
\text { GDP and is either short term or in } \\
\text { foreign currency. }\end{array}$ & \\
\hline 3.2 .3 & Guarantees & $\begin{array}{l}\text { Good: Guarantees is limited by law. } \\
\text { Information on guarantees and their } \\
\text { beneficiaries is published quarterly. }\end{array}$ & $\begin{array}{l}\text { Medium: Exposure from guarantees is } \\
\text { moderate ( } 3.9 \text { percent of GDP at end- } \\
2014) \text {, but call probabilities are high. }\end{array}$ & \\
\hline 3.2 .4 & $\begin{array}{l}\text { Public-Private } \\
\text { Partnerships }\end{array}$ & $\begin{array}{l}\text { Not Met: There is no regular report on } \\
\text { public-private partnerships including } \\
\text { projected receipts and payments over } \\
\text { the lifetime of the contracts. }\end{array}$ & $\begin{array}{l}\text { High: Signed contracts create total } \\
\text { fiscal costs of at least } 7 \text { percent of } \\
\text { GDP, and more contracts are planned. }\end{array}$ & 3.1 \\
\hline 3.2 .5 & $\begin{array}{l}\text { Financial-Sector } \\
\text { Exposure }\end{array}$ & $\begin{array}{l}\text { Advanced: The Bank of Albania } \\
\text { discusses financial stability, and the } \\
\text { Deposit Insurance Agency reports } \\
\text { insured deposits. }\end{array}$ & $\begin{array}{l}\text { High: Insured deposits are } 62 \text { percent } \\
\text { of GDP, and the financial sector is } \\
\text { exposed to significant risks. }\end{array}$ & \\
\hline 3.2 .6 & Natural Resources & $\begin{array}{l}\text { Not Met: Royalties shown in the } \\
\text { budget, but the volume and value of } \\
\text { major natural resources and annual } \\
\text { sales are not regularly reported. }\end{array}$ & $\begin{array}{l}\text { Low: Royalties, though they could } \\
\text { grow, are less than } 2 \text { percent of } \\
\text { government revenues. }\end{array}$ & \\
\hline 3.2 .7 & $\begin{array}{l}\text { Environmental } \\
\text { Risks }\end{array}$ & $\begin{array}{l}\text { Basic: Environmental risks are } \\
\text { discussed in qualitative terms, but } \\
\text { their possible fiscal cost is not } \\
\text { considered in budget documents. }\end{array}$ & $\begin{array}{l}\text { Medium: In recent years, the average } \\
\text { annual fiscal costs of natural disasters } \\
\text { have been only } 0.02 \% \text { of GDP, but a } \\
\text { large disaster would be very costly. }\end{array}$ & \\
\hline 3.3.1 & $\begin{array}{l}\text { Subnational } \\
\text { Governments }\end{array}$ & $\begin{array}{l}\text { Good: The finances of local } \\
\text { governments, individually and as a } \\
\text { sector, are reported at least quarterly } \\
\text { and their debt controlled by law. }\end{array}$ & $\begin{array}{l}\text { High: Local governments' spending is } \\
2.4 \text { percent of GDP and their debt is } \\
\text { less than } 0.1 \text { percent of GDP, but } \\
\text { arrears could be high. }\end{array}$ & \\
\hline 3.3.2 & $\begin{array}{l}\text { Public } \\
\text { Corporations }\end{array}$ & $\begin{array}{l}\text { Basic: The budget includes direct } \\
\text { transfers to public corporations, but } \\
\text { quasi-fiscal activities are not discussed. }\end{array}$ & $\begin{array}{l}\text { High: The liabilities and losses of the } \\
\text { largest } 13 \text { companies were } 20 \text { percent } \\
\text { and } 1 \text { percent of GDP, respectively, in } \\
2013 .\end{array}$ & 3.1 \\
\hline
\end{tabular}

